\title{
GTGS Gerçekleme Problemleri İçin Akıllı Çözümlerin Endüstriyel Bir Robot Manipülatöre Uygulanması
}

\author{
Tolga Yüksel ${ }^{1 *}$
}

Geliş / Received: 31/01/2020

Revize / Revised: 20/07/2020

Kabul / Accepted: 20/07/2020

ÖZ

Görüntü-tabanlı görsel servolama (GTGS) duruş kestirimi gerektirmediğinden robot manipülatörler için popüler GS yaklaşımlarından biridir. GTGS teorik sorunların yanında gerçekleme sırasındaki sorunlarla da baş etmek zorundadır. Bu gerçekleme sorunlarından temel üç tanesi sırasÜıyla etkileşim matrisinin tersinin eldesi, kontrolör için uygun bir sabit kazanç değerinin tanımlanması ve özniteliklerin görüş alanı içinde tutulmasıdır. GTGS için etkileşim matrisi her ne kadar yalancı tersi ile beraber kullanılsa da tekilliklerin oluşması durumunda kontrol yasası işleyememektedir. Diğer bir taraftan sabit kazanç değeri yakınsama hızı ile uç işlevci hızları arasında bir ödünleşmeye sebep olmaktadır. GTGS işleyişi sırasında özniteliklerin görüş alanını terk edebilmesi de yaygın bir sorundur. Bu çalışmada bu sorunları çözmek için önerilen akıllı yaklaşımların endüstriyel tipte bir robot manipülatör üzerine uygulanması hedeflenmiştir. Uygulamanın ilk aşaması olarak akıllı yaklaşımcı birimler etkileşim matrisinin tersinin yerini almakta ve tekillik sorunu ortadan kalkmaktadır. İkinci aşama olarak sabit kazanç yerine her çevrimde hata ve hata türevinin değerine göre kazanç hesabı yapan bir bulanık mantık birimi kullanılmıştır. Üçüncü aşamada ise alınan görüntü düzleminde bölgeler tanımlanmış, bir bulanık mantık birimi yardımıyla özniteliklerin görüş alanı içerisinde kalması sağlanmıştır. Çalışmada tüm gerçeklemelere dair deneysel sonuçlar sunulmuş ve tartışılmıştır.

Anahtar Kelimeler- Görüntü Tabanlı Görsel Servolama, Robot Manipülatör, Bulanık Mantı, Yapay Sinir A $\breve{g} \mathrm{I}$

1*Sorumlu yazar iletișim: tolga.yuksel@bilecik.edu.tr (https://orcid.org/0000-0003-4425-7513)

Elektrik-Elektronik Mühendisliği Bölümü, Bilecik Şeyh Edebali Üniversitesi, Bilecik, Türkiye 


\title{
Implementation of Intelligent Solutions for IBVS Realization Problems to an Industrial Robot Manipulator
}

\begin{abstract}
Image-based visual servoing (IBVS) is one of the popular VS approaches for robot manipulators since it does not require pose estimation. IBVS has to cope with theoretical problems as well as problems during implementation. The main three of these realization problems are obtaining the inverse of the interaction matrix, defining a suitable constant gain value for the controller, and keeping the features in the field of view, respectively. Although the interaction matrix for IBVS is used with the pseudoinverse, the control law does not work if singularities occur. On the other hand, the constant gain value causes a trade-off between the convergence speed and the end-effector speed. It is also a common problem that the features may leave the field of view during IBVS operation. In this study, it is aimed to implement the intelligent approaches proposed to solve these problems on an industrial type robot manipulator. As the first stage of the implementation, the intelligent approximation units take the place of the inverse of the interaction matrix and the problem of singularity disappears. As a second stage, instead of a fixed gain, a fuzzy logic unit which calculates gain according to the value of error and error derivative in each iteration is used. In the third stage, regions are defined in the image plane, and the features are kept within the field of view with the help of a fuzzy logic unit. In this study, experimental results of all implementations are presented and discussed.
\end{abstract}

Keywords- Image Based Visual Servoing, Robot Manipulator, Fuzzy Logic, Artificial Neural Network 


\section{GİRIŞ}

Otomasyon sistemlerinde artan robot sayısı ile insana ait özelliklerin robotlara kazandırılmasında önemli aşamalar kaydedilmiştir. Bu özelliklerden en önemli olanı görmedir. Robotlarda görsel geribesleme terimi ilk olarak Hill ve Park tarafindan kullanılmış [1], daha sonra yerini görsel servolama (GS) terimine bırakmıştır [2]. GS görüntü işleme, robot kinematik kontrolü ve kontrol teorisi alanlarını bir araya getirmektedir. Kameranın robot manipülatör uç işlevcisi üzerine monte edildiği eldeki göz ve kameranın uç işlevcisini görecek şekilde monte edildiği ele göz donanım konfigürasyonları ile GS robot manipülatörler yanında insansız hava araçlarına da uygulanabilir hale gelmiştir.

GS robot uç işlevcisinin 3B uzayda doğrusal ve açısal hızlarını belirlemek amacından yola çıkmaktadır. Bunun için öncelikle kamera görüntü düzleminde tanımlanan $k$ öznitelikleri belirlenerek bir $s$ öznitelik vektörü oluşturulmaktadır. Daha sonra istenen öznitelik vektörü $\left(s^{*}\right)$ ile bu vektör arasındaki farktan yararlanarak bir hata vektörü oluşturulmaktadır. Öznitelikler nokta, çizgi ve daire vb. formlarda olabilmektedir [3]. Burada, öznitelik tabanlı GS yaklaşımlarının yanında çekirdek fonksiyonu tabanlı veya parlaklık tabanlı yaklaşımların da olduğu belirtilmelidir [4], [5]. GS için son adım olarak oluşturulan hata vektöründen yararlanarak bir kinematik hız kontrol yasası tanımlanmaktadır. Bu adımlar içinde GS iki ana tipe ayrılmaktadır. Görüntü tabanlı görsel servolama (GTGS) görüntüden elde edilen $s$ özniteliklerini doğrudan kinematik kontrolcü tasarımı için kullanırken konum tabanlı görsel servolama (KTGS) $s$ özniteliklerini robotun duruş kestirimi için kullanmaktadır [3]. Duruş kestiriminin getirdiği sorunlar ve GTGS'nın kalibrasyon hatalarına karşı gürbüzlüğü uygulamalarda GTGS'yı daha yaygın kılmaktadır. Bu çalışma bu üstünlüğünden dolayı GTGS’ya odaklanmıştır.

GTGS çalışmaları daha çok teori düzeyinde kaldığından özellikle farklı öznitelik çıkarma yöntemlerine [6]-[8], farklı kamera tipleri ve geometrilerine [9], GTGS ve KTGS yaklaşımlarının üstünlüklerini birleştiren melez GS yöntemlerine [10]-[12] odaklandığı görülmektedir. Endüstriyel bir GS uygulamasına bakıldığında ise bu yaklaşımlardan farklı olarak etkileşim matrisi yalancı tersi eldesi, uygun kazanç değeri atama ve öznitelikleri görüş alanı içinde tutma gibi problemlerin öne çıktı̆̆ görülmektedir. Etkileşim matrisi gerçek dünyadaki 3B bir noktanın doğrusal ve açısal hızlarının 2B görüntü düzlemine izdüşüm yaparak bu düzlemdeki hızlara ilişkisini ortaya koymaktadır. Bu matrisin boyutları öznitelikler tarafından belirlendiğinden kare matris her zaman mümkün olmamaktadır. GTGS, kontrol yasasını tanımlarken bu etkileşim matrisinin tersine ihtiyaç duyduğundan yalancı tersi kullanımı gerekmektedir. Yalancı tersinin eldesi ise bazı GS senaryolarında mümkün olmamakta ve tekilliğe sebep olmaktadır [13]. Yakınsamış bir etkileşim matrisi veya tersi bu probleme çözüm getirebilmektedir. Kumar and Behera stereo kameralı ele göz konfigürasyonuna sahip bir fazlalıklı robot manipülatör için kendinden organize haritaları (SOM) kullanarak etkileşim matrisine yakınsama elde etmişlerdir fakat eldeki göz konfigürasyonunu göz ardı etmişlerdir[14]. Kosmopoulos 6 serbestlik dereceli bir manipülatör için doğrusal bir öznitelik seti için en küçük kareler kestirimcisiyle etkileşim matrisine bir yakınsayıcı türetmeye çalışmıştır fakat yakınsayıcı sadece bir yörünge için tanımlanmıştır [15]. Zhong vd. ise yakınsama için ortak çalışan gürbüz Kalman filtresi ve Elman sinir ağı önermişlerdir fakat sistemin tanımladığı uç işlevci hızlarının gerçekçiliği göz ardı edilmiştir [16]. Goncalves vd. ise etkileşim matrisini kullanmadan robot hızlarını ters bulanık modelleyici ile modellemeye çalışmışlardır [17]. Çalışmalarında kullandıkları bulanık modelleyici kendinden öğrenme mekanizmasına sahip değildir ve sadece eldeki göz konfigürasyonu göz önünde bulundurulmuştur.

İkinci GS gerçekleme problemi olan uygun kazanç değerini atama GS'in öznitelik hatalarını sıfıra yakınsaması olarak tanımlanan yakınsama süresi veya çevrim sayısını doğrudan etkilemektedir. Büyük kazanç değerleri ile hızlı yakınsama sağlanırken uç işlevci hız limitlerinin aşılması olasıdır. Küçük kazanç değerleri ise yavaş yakınsamaya sebep olmaktadır. Kazanç değerinin öznitelik hatalarına göre uyarlanabilir olması hız limitleri içinde hızlı yakınsamayı sağlayabilecektir. Mansard ve Chaumette çalışmalarında melez bir GTGSKTGS sistemi tasarlamış, GTGS'dan KTGS'ya yumuşak geçiş için uyarlanabilir bir kazanç tanımlamışlardır [18]. Çalışmada hız limitleri tanımlanmamıştır. Başka bir çalışmalarında Kermogant ve Chaumette öznitelik kümesine eldeki göz konfigürasyonlu kameradan alınan öznitelikleri, ele göz konfigürasyonlu kameradan alınan öznitelikleri ve robot sisteminin kısıtlarını eklemiş ve önerdikleri doğrusal karesel bir kontrolcüde uyarlanabilir kazançtan yararlanmışlardır [19]. 
Son GS gerçekleme problemi olan özniteliklerin görüş alanından çıkması problemi ise GS sisteminin ıraksamasına ve GS görevi sırasında ani hız değişimlerine sebep olmaktadır. Bu yıkıcı etkiden korunmak için Corke vd. öznitekleri görüntü sınırlarından uzak tutacak bir diferansiyel potansiyel fonksiyon tanımlamışlardır [11]. Bu fonksiyonun sınır bölgede osilasyona sebep olabileceğini çalışmalarında belirtmişlerdir. Chesi vd. ise özniteliklerin görüntü sınırına gelmesi durumunda uç işlevciyi 3B noktadan uzaklaştıracak bir hız kontrol yöntemi önermişlerdir [20]. Bu yöntem akılcı görünse de yakınsama süresinde uzamaya ve hız kontrol yöntemi değişikliğinin çatırtıya sebep olabileceği çalışmalarında belirtilmiştir.

$\mathrm{Bu}$ çalışmada ise yukarıda bahsedilen bu üç probleme akıllı birimler kullanılarak ayrı ayrı çözümler sunulmuştur. İlk problem olan etkileşim matrisi tersi için akıllı yakınsayıcı temelli yaklaşım önerilmiştir. $\mathrm{Bu}$ öneride yapay sinir ağı (YSA), radyal tabanlı sinir ağı (RTA) ve ekstrem öğrenen makine (EÖM) kullanılmıştır. $\mathrm{Bu}$ üç akıllı birim klasik GTGS ile elde edilen yörüngelerin etkileşim matrisi yalancı tersleri ile eğitilmiş, elde edilen sonuçlar ortalama karesel hataya göre karşılaştırılmıştır. İkinci problemin çözümü için girişleri öznitelik hata ve hata türev vektörlerinin genlikleri olan bir bulanık mantık (BM) birimi tanımlanmıştır. Ayrıca Yoshikawa tarafından manipülatörlerin tekil konfigürasyondan uzaklıklarını bir nicelik olarak tanımladığı hareket uygunluğu da [21] manipülatör sistemini tekil konfigürasyonlardan uzak tutmak üzere BM girişi olarak tanımlanmıştır. Üçüncü problem için ise yine bir BM biriminin özniteliklerin görüntü sınırlarına uzaklıklarına göre hız kontrolcüsünde değişiklik yaptığı bir çözüm önerilmiştir. Bu üç çözüm önerisi eldeki göz konfigürasyonuna sahip bir endüstriyel tipte bir robot manipülatör üzerinde denenerek sonuçlar bu çalışmada sunulmuştur.

Çalışma şu şekilde düzenlenmiştir. Bölüm 2'de GTGS gerçekleme problemleri için akıllı çözüm önerileri ayrıntılandırılmıştır. Bölüm 3'te deney düzeneği anlatılmış ve deneysel sonuçlar ayrıntılı olarak sunulmuştur. Son bölümde ise önerilen çözümler elde edilen deney sonuçlarıyla beraber tartışılmıştır.

\section{II. ÖNERILEN AKILLI GTGS SISTEMI}

Önerilen sistemin genel gösterilimi Şekil 1'de verilmiştir.

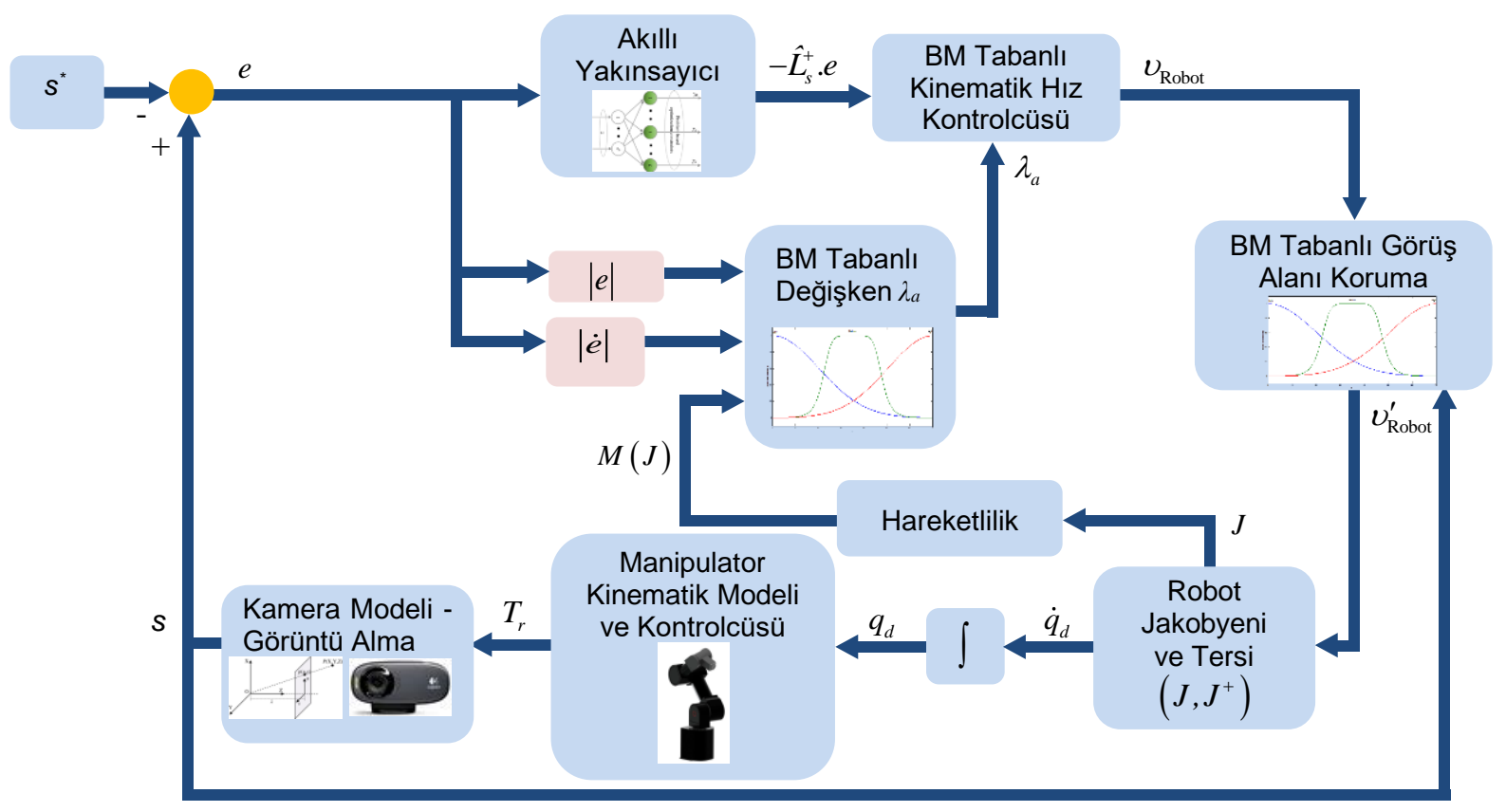

Şekil 1. Önerilen akıllı GTGS sistemi 
Önerilen sistemin ilk adımını görüntü alma ve görüntü bozulmalarının (distorsiyon) giderilmesi oluşturmaktadır. Kullanılan kameraya bağlı olarak alınan görüntüde oluşacak bozulmalar çıkarılacak görüntü özniteliklerinde değişikliğe sebep olabilir. Örneğin 3B dünyadaki nokta şeklinde bir özniteliğin görüntü düzlemine izdüşümü kameradaki görüntü bozulmalarından dolayı etkilenecektir. Bu sebeple kameranın GS çevrimine sokmadan önce mutlaka kalibre edilmesi gerekmektedir. Bunun için bir satranç tahtası görseli ile kameraya belli mesafelerden belirli dönmeler ve farklı perspektiflerle görüntü alınarak bu görüntü üzerinde satranç tahtasındaki kare köşe noktaları belirlenerek kamera matrisi elde edilmeli, elde edilen kamera matrisine dair parametrelerde görüntüde düzeltme yapılmalıdır. Önerilen sistemin ilk adımında kullanılan kamera görüntüsünde bu düzeltme işlemleri yapılmıştır.

Alınan görüntüden nokta şeklinde öznitelik çıkarımı sistemin ikinci adımını oluşturmaktadır. Bu adım için 3 adet nokta için öznitelik çıkartılması uygun görülmüştür. Burada 6 serbestlik dereceli bir robot manipülatör için en az 3 noktaya dair öznitelik gerektiği belirtilmelidir [3].

Önerilen sistemde akıllı bir yakınsayıcı ile etkileşim matrisine yakınsama önerilmiştir. Etkileşim matrisinin analitik eldesi için nokta şeklindeki öznitelikler için iğne deliği modeli ile kamera çerçevesine göre 3B bir noktanın koordinatları belirtildiğinde $(P(X, Y, Z))$, bu noktanın görüntü çerçevesine göre durumu Şekil 2 ile gösterilmiştir.

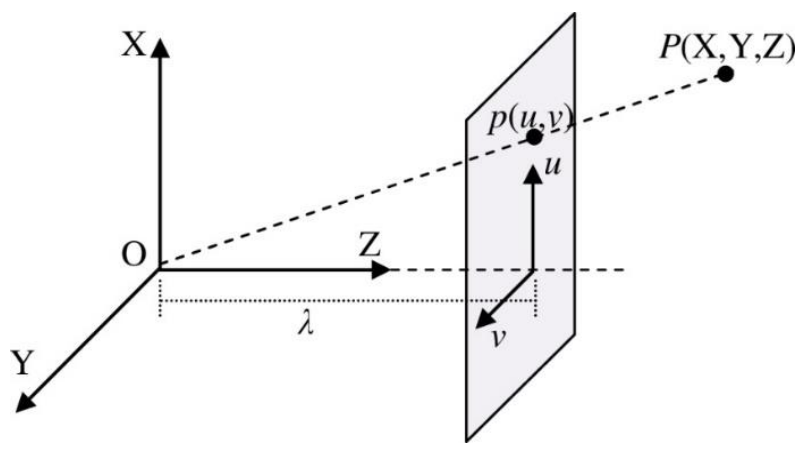

Şekil 2. İğne deliği kamera modeli

Gerekli ara adımlardan sonra [3] nokta şeklindeki öznitelikle görüntü düzlemindeki izdüşümün hızları arasındaki ilişki (1) ile verilmektedir.

$$
\left[\begin{array}{c}
\dot{u} \\
\dot{v}
\end{array}\right]=\left[\begin{array}{cccccc}
-\frac{\lambda}{z} & 0 & \frac{u}{z} & \frac{u v}{\lambda} & -\frac{\lambda^{2}+u^{2}}{\lambda} & v \\
0 & -\frac{\lambda}{z} & \frac{v}{z} & \frac{\lambda^{2}+v^{2}}{\lambda} & -\frac{u v}{\lambda} & -u
\end{array}\right]\left[\begin{array}{c}
v_{x} \\
v_{y} \\
v_{z} \\
\omega_{x} \\
\omega_{y} \\
\omega_{z}
\end{array}\right]=L_{s} \cdot v_{K}
$$

Burada $Z, P$ noktasının derinliğidir ve her zaman elde edilemeyebilir. Bu sebeple $L_{s}$ yerine $\hat{L}_{s}$ kestirimi kullanılabilir. Bu kestirimdeki $Z$ yerine ya istenen bir değer ya da $s^{*}$ durumundaki $Z$ değeri kullanılır. Yukarıdaki eşitlik sadece bir nokta özniteliğe aittir ve her bir öznitelik noktası için ayrı ayrı elde edilmelidir. Buradan yola çıkarak her bir öznitelik noktasının etkileşim matrisinin satır sayısını 2 arttırdığı söylenebilir.

Öznitelik hatalarının üstel azalması için sisteme kontrol sinyali olarak hızı vermek üzere aşağıdaki kontrolcü tasarım adımı izlenir [3]:

$$
\dot{e}+\lambda . e=0 \Rightarrow \dot{e}=-\lambda . e \Rightarrow L_{s} \cdot v_{K}=-\lambda . e \Rightarrow v_{K}=-\lambda . L_{S}^{+} . e
$$

Burada $L_{s}^{+}$etkileşim matrisinin yalanc1 tersi, $\lambda$ ise kazanç değeridir. (1) ile verilen etkileşim matrisinin analitik tanımlı yalancı tersinde oluşabilecek tekillikler [13] yerine önerilen sistemde akıllı bir yakınsayıcı ile 
etkileşim matrisine yakınsama önerilmiştir. Burada doğrudan etkileşim matrisine yakınsamanın getirdiği bir zayıflıktan bahsetmek gerekmektedir. Etkileşim matrisinin boyutu $L_{s} \in \mathbb{R}^{k \times 6}$ ile tanımlandığından öznitelik sayısına göre yakınsayıcı çıkışı tekrar ayarlanmalıdır. Bunun yerine $-\hat{L}_{s}^{+}$.e değerine yakınsamak sabit sayıda çıkışı sağlamaktadır. Burada ağ girişi her bir özniteliğe dair hata vektörü olacaktır. Ağdan beklenen ise kestirilmiş etkileşim matrisi tersi ile hata vektörü çarpımının oluşturduğu fonksiyona yakınsamasıdır. Bu sayede öznitelik nokta sayısıyla değişen etkileşim matrisi eleman sayısı yerine öznitelik nokta sayısından bağımsız, sadece doğrusal ve açısal hızlara etkiyen 6 çıkış bulunmuştur.

Sistemde akıllı yakınsayıcı olarak uygun sayıda nörona sahip YSA, RTA ve EÖM kullanılmıştır. Bu ağların eğitimi için klasik GTGS (sabit kazanç varken ve görüş alanı koruması olmadan) ile farklı başlangıç konum ve duruşlarında farklı başlangıç öznitelikleri için elde edilen veriler alınmış ve eğitim için kullanılmıştır.

Pratik GS uygulamalarında her ne kadar başarım kriteri olarak yakınsama hızı alınsa da endüstriyel uygulamalarda önem taşıyan hız limitleri göz ardı edilmektedir. Kontrol edilen bir robot manipülatörden istenen üretim hattında daha fazla iş yapabilmesidir. Bunu sağlayabilmek için GS'nın hız limitleri içinde daha hızlı yakınsaması sağlanmalıdır. Robot manipülatörün yeteneklerine bağlı bu hız limitleri içinde daha hızlı yakınsama için zamanla değişen bir kazanç değeri tanımlanmalıdır. Bu tanımlamada özellikle kazanç çizgeleme çalışmalarında etkin olarak kullanılan BM'dan yararlanılabilir [22]. Önerilen sistemde hata ve hata türevine ait norm değerlerini $(\|e\|,\|\dot{e}\|)$ giriş olarak alan olan bir BM birimi uyarlanabilir $\lambda_{a}$ çıkışını vermektedir. Bu çıkış değeri de BM tabanlı GS kinematik hız kontrolcüsüne aktarılmaktadır.

Değişen $\lambda_{a}$ değeri hız profillerini değiştirirken robot manipülatörlerin endüstriyel uygulamalarında önemli olan başka bir terim de önerilen sistemde göz önünde bulundurulmuştur. Robot manipülatörler için yörünge planlaması yapan çalışmalarda eklem sınırları ve çarpışmadan kaçınma koşulları önemli kısıtlardır. GS yaklaşımını bir yörünge planlama görevi olarak düşünen çalışmalar ilke olarak önce yörüngenin türetilmesi ile ilgilenir [23], [24]. Bu türetim için ise homografi tabanlı hareket planlama gerekir. GTGS için hareket planlama yapılması proje kapsamı dışındadır fakat manipülatör hareketlerindeki bir kısıt olan hareketlilik önerilen sistemde göz önünde bulundurulmuştur. Hareketlilik, hız sınırlarının, herhangi rasgele bir duruşta hareket etme kabiliyetinin ve tekillikten kaçınmanın global bir ölçütüdür ve değeri aşağıdaki gibi tanımlanmaktadır:

$$
M=\sqrt{\operatorname{det}\left(J(q) \cdot J(q)^{T}\right)}
$$

Yukarıdaki formülde $J(q)$ robot jakobyenini tanımlamaktadır. Bu sebeple önerilen sistemde uç işlevcisi hızları bulunduktan sonra robot jakobyeni her bir çevrimde bulunarak hareketlilik hesabı için kullanılmaktadır. (3) ile tanımlı ölçüt önerilen sistemde değișen kazanç ile birlikte yüksek hızlarla hızlı yakınsama sağlanırken robot hareketi hakkında bilgi sağlayarak hız sınırlandırmaya yardımcı olması hedeflenmiştir. Şekil 1'de gösterildiği üzere bu ölçüt terimi de BM birimi girişi olarak bulunmaktadır. BM biriminin kuralları ve üyelik fonksiyonları tanımlanırken hız sınırları üzerindeki etkileri de göz önünde bulundurulmuştur.

Görüş alanı koruma için ise öncelikle görüntü içinde bölge tanımlamaları yapılmış ve bu tanıma ait gösterilim Şekil 3'te verilmiştir. Bu bölgeler sayesinde öznitelikler görüntü kenarına gelmeden gerekli önlemler alınabilmiştir. Literatürde bu gibi durumlarda önlem olarak öznitelikleri görüntü merkezine doğru yönlendirmek için hedef özniteliklerden uzaklaşarak onları görüntü merkezine sürükleyen $-Z$ yönünde bir hareket önerilmiştir [20]. Bu yaklaşım uygun bir yaklaşım gibi görünse de hedeften uzaklaşıldığı için yakınsama zamanını uzatmaktadır. Ayrıca bu ani manevra, hız işaretlerinde çatırtıya sebep olabilir. Önerilen sistemde bu yaklaşımın yerine yaklaşılan kenara ait doğrusal hız bileşenine $\left(v_{x}\right.$ veya $\left.v_{y}\right)$ negatif bir hız etkisi eklenerek özniteliklerin görüntü merkezine yöneltilmesi sağlanmaktadır.

Sistem için tanımlanan üç bölgede aşağıdaki durumlar tanımlanmıştır:

- $\quad$ Eğer özniteliklerden hepsi Bölge A içinde ise Şekil 3'da gösterilen Bölge A güvenli bölge sayıldığından hız bileşenleri GTGS tarafindan belirlendiği halde kalmalıdır.

- Eğer özniteliklerden herhangi biri Bölge B’ye geçiş yaptıysa nokta özniteliğin giriş yaptığı kenara ait negatif bir doğrusal hız bileşeni belirlenecek ve mevcut doğrusal hıza eklenmelidir. Bu hız değişimini 
yumuşak geçişle sağlayacak bir birime ihtiyaç duyulmaktadır. Önerilen sistem bu amaçla yine bir BM birimine başvurmaktadır. Bu birim, giriş olarak kenara en yakın özniteliğin koordinatlarını almakta, Şekil

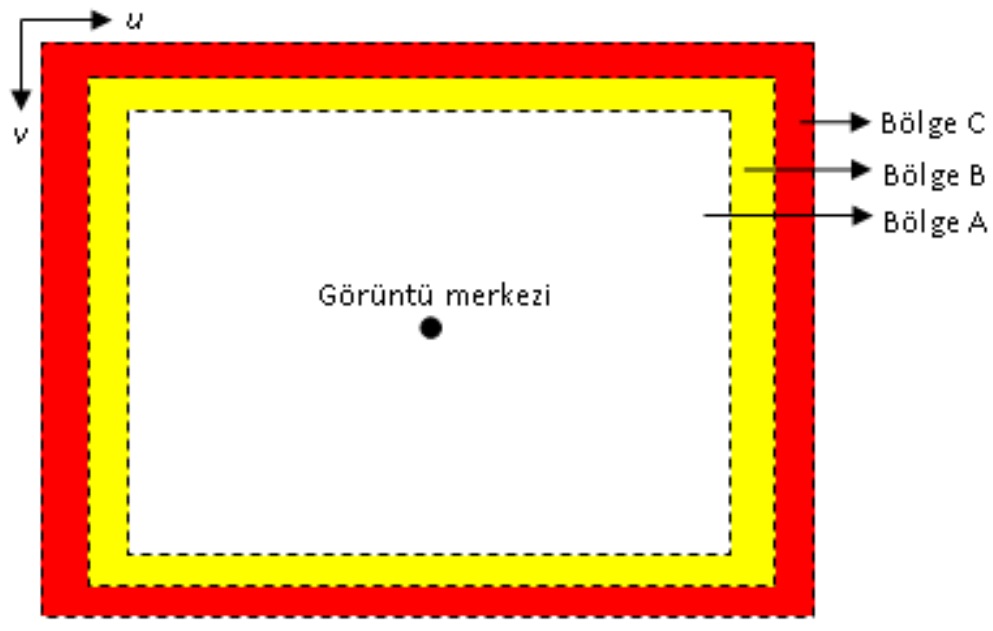

Şekil 3. Görüş alanını korumak için görüntü bölge tanımları

3'daki Bölge B için negatif hız değerini oluşturarak mevcut hıza eklemektedir. Elde edilen hız vektörü olarak adlandırılarak robot manipülatöre dair hız vektörü tamamlanmış olmaktadır.

- Eğer özniteliklerden biri Bölge C'ye geçiş yaptıysa özniteliğin yaklaştığı kenara ait uygulanabilecek en büyük negatif hız mevcut hıza eklenmektedir.

Elde edilen uç işlevci hızları, robot jakobyeni ve tersi kullanılarak eklem hızları elde edilmekte ve robot iç dinamik kontrolcüsüne aktarılmaktadır. Kontrolcü içindeki bağımsız eklem PID kontrolcü sayesinde iç dinamik kontrolü sağlanmaktadır. Bu kontrolle beraber hareket eden uç işlevci-kamera ile yeni görüntü çerçevesi alınmakta, alınan görüntüden yeni öznitelikler elde edilerek GS kapalı çevrimi tamamlanmaktadır.

\section{DENEYSEL SONUÇLAR}

Önerilen akıllı GTGS sisteminde kullanılan Acrobot isimli robot manipülatör ACROME firmas1 tarafından geliştirilmiş olup 6 döner eklemli, $\pm 0.1 \mathrm{~mm}$ hassasiyete, tam açık durumda $760 \mathrm{~mm}$ uzunluğa ve $1 \mathrm{~kg}$ yük taşıma kapasitesine sahip bir robot manipülatördür. Robot manipülatörün her bir eklemindeki Dynamixel PRO serisi akıllı servo motorlar firçasız veya çekirdeksiz DA motor, redüktör ve sürücüyü bir araya getirmekte, bu sayede sadece USB ve güç bağlantısıyla doğrudan programlamaya izin vermektedir. Acrobot eklemlerinde Dynamixel Pro L54, H54 ve M42 serisi motorlar bulunmaktadır. Manipülatörün sabitlenmiş görüntüsü, eklem dönüş yönleri ve uç işlevciye bağlanmış olan Logitech C310 kamera Şekil 4 'te gösterilmektedir. Robota dair DH parametreleri ise Tablo 1'de verilmektedir.

Önerilen sistemde yazılım ortamı olarak MATLAB-Simulink (R2017b) Camera Calibration Toolbox, Robotics Toolbox 9.0, Neural Network Toolbox, Fuzzy Logic Toolbox ve NI LabVIEW 2018, NI Dynamixel API, NI Vision for LabVIEW, NI IMAQ VI, NI Vision Acquisition Express VI yazılımlarından yararlanılmıştır. Önerilen sisteme ait yazılımlar Core i5 işlemcili 8 GB RAM, GTX 1050 Ti ekran kartına sahip bir masaüstü bilgisayar kullanılarak hazırlanmıştır.

Kamera parametrelernin çıkarımı için önce bir satranç tahtası şeklinde bir örüntü oluşturulmuştur. Burada örüntü üzerindeki her bir karenin kenar uzunluğu parametre çıkarımı için gereklidir. Çalışmada kullanılan örüntüde her bir karenin kenar uzunluğu 24 mm'dir. Daha sonra Camera Calibration Toolbox tarafından tavsiye edildiği üzere kameraya sabit bir mesafeden farklı perspektiflerle örüntünün 10 farklı görüntüsü $1024 \times 768$ çözünürlükte alınmıştır. Örüntüdeki köşe noktalarının örnek görüntüler arasındaki karşılaştırması yapılarak Logitech $\mathrm{CH} 310$ 'a dair kamera parametreleri çıkarılmıştır. Elde edilen kamera 
parametreleri Tablo 2'de verilmiş olup üretilen her bir kameranın bozulmalarının kendine has olduğu, elde edilen bu parametrelerin farklı bir $\mathrm{CH} 310$ kamerada farklı olacağı belirtilmelidir.

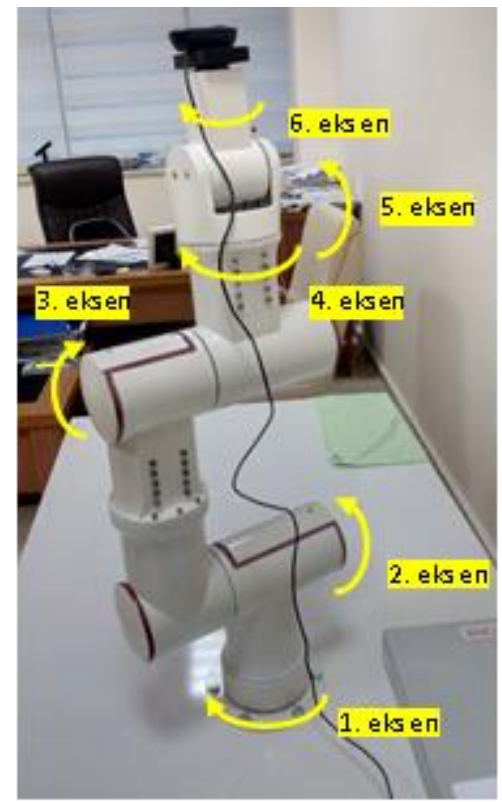

Şekil 4. Acrobot robot manipülatör ve Logitech CH310 kamera

Tablo 1. Acrobot DH parametreleri

\begin{tabular}{ccccc}
\hline Eklem No & $\boldsymbol{a}(\mathbf{c m})$ & $\boldsymbol{\alpha}$ & $\boldsymbol{d}(\mathbf{c m})$ & $\boldsymbol{\theta}$ \\
\hline 1 & 0 & $\pi / 2$ & 17 & $\theta_{1}$ \\
2 & 27.8 & 0 & 14 & $\theta_{2}$ \\
3 & 0 & $-\pi / 2$ & 14 & $\theta_{3}$ \\
4 & 0 & $\pi / 2$ & 14 & $\theta_{4}$ \\
5 & 0 & $-\pi / 2$ & 0 & $\theta_{5}$ \\
6 & 0 & 0 & 15 & $\theta_{6}$ \\
\hline
\end{tabular}

Tablo 2. Logitech $\mathrm{CH} 310$ kamera parametreleri

\begin{tabular}{|c|c|c|c|}
\hline Radyal Distorsiyon & \multicolumn{3}{|c|}{$\left[\begin{array}{lll}-0.1618 & 0.8119\end{array}\right]$} \\
\hline Tanjant Distorsiyon & \multicolumn{3}{|c|}{$\left[\begin{array}{ll}0 & 0\end{array}\right]$} \\
\hline İçsel(Intrinsic) Matris & $\begin{array}{c}1049.5 \\
0 \\
490.7 \\
\end{array}$ & $\begin{array}{c}0 \\
1048.5 \\
378.8 \\
\end{array}$ & $\begin{array}{l}0 ; \\
0 ; \\
1]\end{array}$ \\
\hline Odak Uzaklığı & \multicolumn{3}{|c|}{ [1049.5 1048.5$]$} \\
\hline $\begin{array}{c}\text { Merkez Noktası } \\
\text { Koordinatları }\end{array}$ & \multicolumn{3}{|c|}{ [490 378] } \\
\hline
\end{tabular}


Projede hedef öznitelikler olarak nokta öznitelikler seçilmiştir. Nokta özniteliklerin kullanımındaki zorluk nokta özniteliklerin hedef özniteliklerle sürekli aynı şekilde eşleşmesini sağlamaktır [13]. Bu zorluğu aşmak için öznitelik olarak içi dolu üç farklı çaplarda daire oluşturulmuş ve bu dairelerin merkezleri nokta öznitelikler olarak seçilmiştir. Daire merkezlerinin bulunmasında görüntü alımından sonra 8'li piksel komşuluğu ile oluşan kapalı kontürlerin alanları bulunmuş, alan merkezleri ise toplam kontür piksel koordinatlarının kontür piksel sayısına bölümüyle elde edilmiştir [25]. Burada bu merkez piksellerin elde edilişinde aydınlatma koşullarının oldukça etkili olduğu belirtilmeli, GTGS uygulamaları için çoğunlukla harici bir 1şık kaynağı ile çalışma uzayının aydınlatılması gerektiği belirtilmelidir [3]. Öznitelik çıkarımına dair örnek bir görüntü mevcut $\left(\right.$ sar1*$\left.^{*}\right)$ ve hedef $($ kırmızı + ) öznitelik gösterilimleriyle beraber Şekil 5 'te verilmiştir. Burada deneyler boyunca kamera çözünürlüğünün $1280 \times 960$ seçildiği belirtilmelidir.

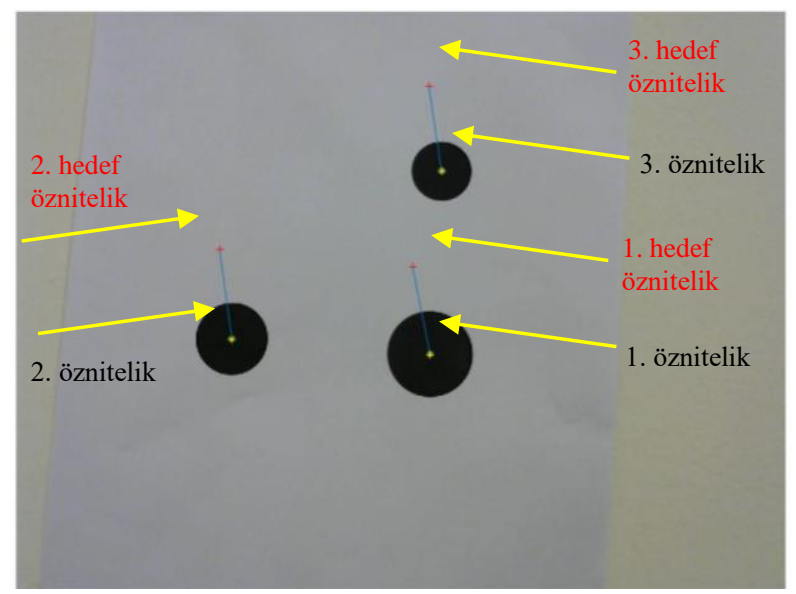

Şekil 5. Örnek kamera görüntüsü ve öznitelik gösterilimleri

\section{A. Klasik GTGS Sistemi Sonuçları}

Önerilen sistemle karşılaştırma yapabilmek adına klasik GTGS sistemine dair bulgular öncelikle verilecektir. Örnek olarak (4)'teki hedef özniteliklere $\left(s^{*}(u, v)\right)$ ve hedef özniteliklere dair robot eklem konum vektörüne $\left(q^{*}\right)$ sahip, $\lambda=0.5$ için klasik GTGS senaryo sonuçları Şekil 6'da verilmiştir. Burada başlangıç konum vektörünün $(q(0))$ Eş. (5)'de verildiği belirtilmelidir.

$$
\begin{aligned}
& s^{*}(u, v)=\left[\begin{array}{llll}
822 & 438 & 792 \\
626 & 634 & 295
\end{array}\right] \\
& q^{*}=\left[\begin{array}{lllllll}
-23.3 & -4.1 & -71.3 & 2.2 & 66.5 & -83.9
\end{array}\right]^{\circ} \\
& q(0)=\left[\begin{array}{llllll}
-21.7 & -32.1 & -71.3 & -7 & 65.5 & -82.9
\end{array}\right]^{\circ}
\end{aligned}
$$

Şekil 6.a görüntü düzlemindeki 3 öznitelik noktasının başlangıç duruşu verilmektedir. Özniteliklerin hedef özniteliklerle ilişkisini göstermek adına her bir özniteliğin bağlı olduğu hedef sırasıyla kırmızı yeşil ve mavi çizgilerle birbirine bağlanmış, kırmızı + sembolüyle hedef öznitelikler gösterilmiştir. Şekil 6.b'de ise 3 öznitelik noktasının bitiş duruşu verilmektedir. Şekil 6.c'de ise özniteliklerin klasik GTGS ile izlediği yörüngeler sırasıyla kırmızı yeşil ve mavi renklerle verilmektedir. Şekil 6.d'de ise uç işlevcisine ait 3B uzaydaki hızlar verilmiştir. Bu hızlar incelendiğinde 148. iterasyonda ani bir hız değişimi göze çarpmaktadır. Bu ani değişim etkileşim matrisindeki işaret değişimlerine bağlı olarak yalancı tersinin getirdiği bir ani değişimdir. Sistemin bu tip değişimlerden uzak tutabilmek amacıyla hız türevine sınırlama getirilmiştir.

Şekil 6.e'de ise özniteliklere dair hatalar gösterilmiştir. Öznitelik hatalarının sıfıra yakınsadığı açıkça görülmektedir. Buradaki kalıcı hatalar ise hedef öznitelikler için tanımlanan değerlerin elde edilmesi sırasında kameranın getirdiği bozulmadan ve kameranın aydınlatma koşullarından kaynaklandı̆̆ı belirtilmelidir. 


\section{B. Önerilen GTGS Sistemi Sonuçları}

Önerilen GTGS sisteminin ilk adımı olan akıllı yakınsayıcılar ile etkileşim matrisi tersine yakınsarken yakınsayıcı girişi her bir özniteliğe dair hata vektörü olacaktır. Yakınsayıcıdan beklenen ise kestirilmiş etkileşim matrisi tersi ile hata vektörü çarpımının oluşturduğu fonksiyona yakınsamasıdır. Bu sayede öznitelik nokta sayısıyla değişen etkileşim matrisi eleman sayısı yerine öznitelik nokta sayısından bağımsız, sadece doğrusal ve açısal hızlara etkiyen 6 çıkış bulunacak, böyle akıllı birimin yapının 6 giriş- 6 çıkışlı olacaktır. Sistemde akıllı yakınsayıcı olarak YSA, RTA ve EÖM kullanılmıştır. Bu akıllı yakınsayıcılarının yakınsama işlemini yapabilmesi için öncelikle oluşturulan bir eğitim veri kümesiyle öğrenme aşamasından geçmesi gerekir. Akıllı yakınsayıcılar için eğitim verileri klasik GTGS ile elde edilmiştir. Eğitim verisi oluşturulurken yakınsama başarımını artırmak için olası tüm görsel servolama senaryolarını içerecek şekilde bir veri kümesi hazırlanmalıdır. $\mathrm{Bu}$ sebeple farklı başlangıç öznitelik matrisine sahip klasik GTGS ile veriler toplanıp birleştirilmiştir. Hedef özniteliklerine dair matris ve bu özniteliklere dair robot eklem konum vektörü (5) ile tanımlanmıştır. Derinlik için kestirim olarak da $\hat{Z}=0.30 \mathrm{~m}$. kullanılmıştır.

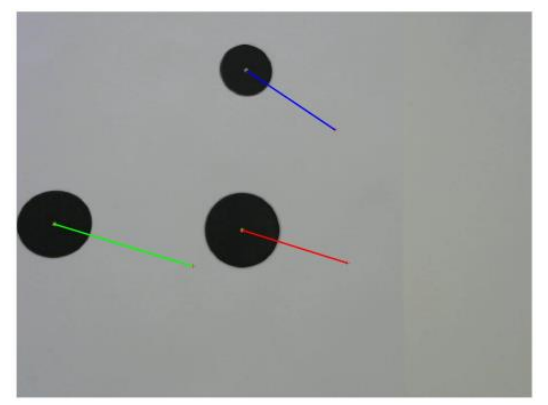

(a)

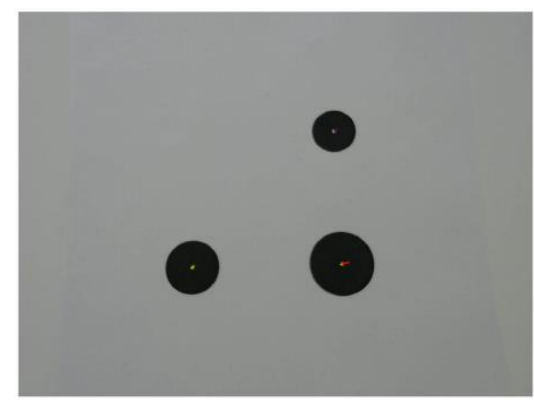

(b)

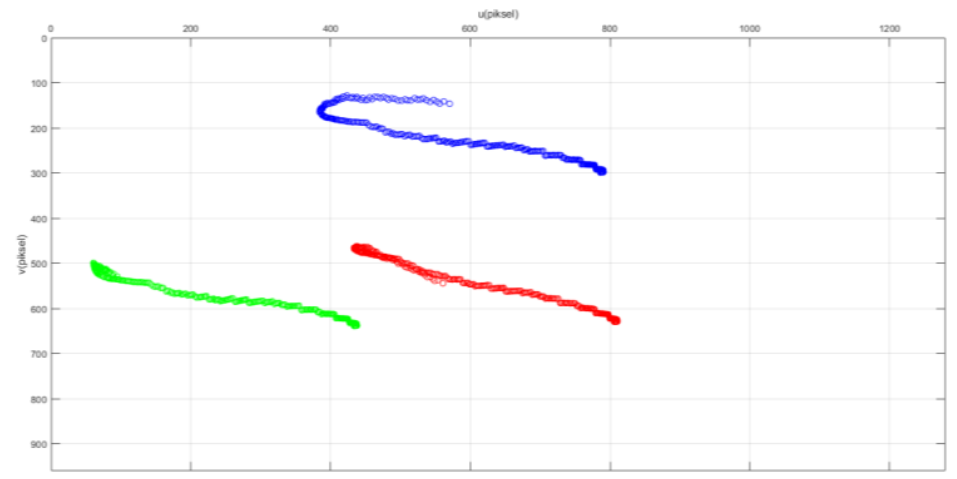

(c) 

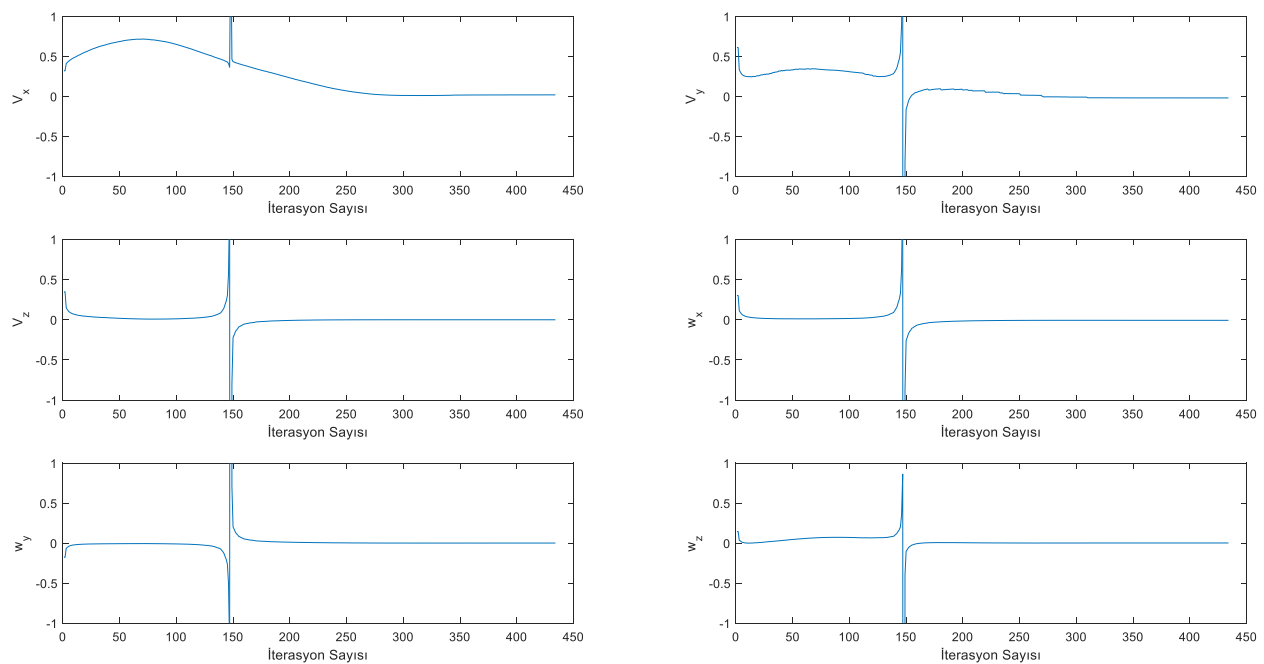

(d)

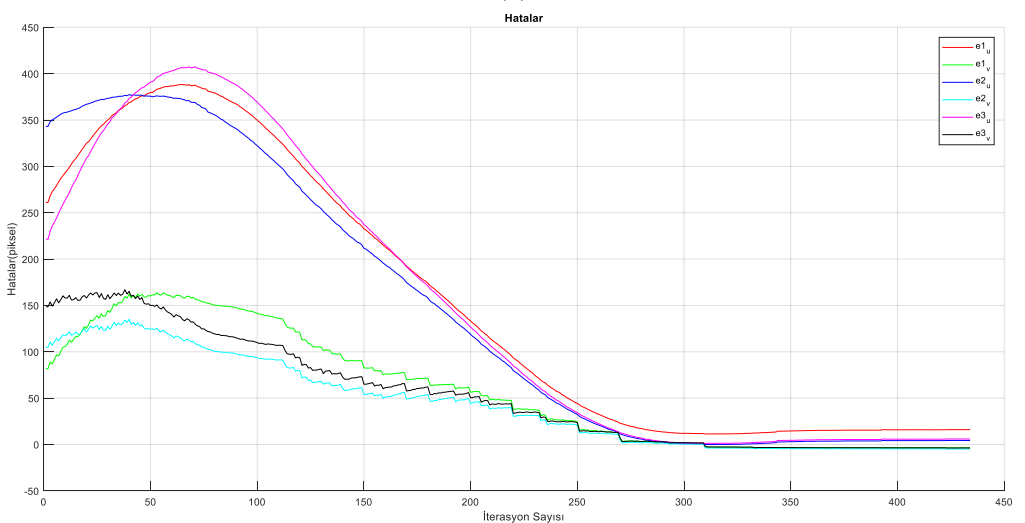

(e)

Şekil 6. Klasik GTGS sonuçları (a) Özniteliklerin başlangıç duruşları (b) Özniteliklerin bitiş duruşları (c) Öznitelik yörüngeleri (d) Uç işlevcisine ait 3B hızlar (e) Öznitelik hataları

Veri kümesi hazırlama için görüntü düzlemi 4 bölgeye ayrılmış ve her bölgeden 5 farklı başlangıç noktasıyla yukarıdaki hedefe ulaşmaya çalışan klasik GTGS verileri alınmıştır. Her bir veri kümesi için 344 örnek alınmıştır. Akıllı yakınsayıcıların başarımını artırmak için her bir çıkış için bir yakınsayıcı kullanılmıştır. Böylece girişi $6 \times(344 \times 20)$, çıkışı $1 \times(344 \times 20)$ boyutlu verilerle akıllı yakınsayıcılar eğitilmiştir.

YSA oluşturma ve eğitimi için MATLAB Neural Network Toolbox kullanılmıştır. İlk olarak her biri 3 katmanlı 6 YSA her biri bir çıkış için eğitilmek üzere oluşturulmuştur. Bu YSA'ların birinci ve ikinci katmanında 10'ar nöron bulunmaktadır ve bu nöronlar aktivasyon fonksiyonu olarak tanjant sigmoid kullanmaktadır. Çıkış katmanlarında ise her birinde tek çıkış olduğu için 1 nöron bulunmaktadır ve YSA'lar fonksiyon yakınsama yaptığından bu nöronlar doğrusal tipte aktivasyon fonksiyonu kullanmaktadır. YSA'lar literatürde en başarılı kabul edilen Resilient Backpropagation (RP) ve Levenberg-Marquart (LM) algoritmaları ile eğitilmiş [26], LM algoritmasının başarımı daha yüksek olduğundan bu algoritma ile devam edilmiştir. Hata hedefi olarak sıfır ve 1000 eğitimi adımı (epoch) sonunda YSA'lara dair elde edilen ortalama karesel hata (MSE) değerleri Tablo 3’te verilmiştir.

Tablo 3 incelendiğinde 3 ve 5 no'lu YSA'ların MSE değerlerinin yüksek olduğu görülmektedir. Bunun sebebi yakınsanacak fonksiyondaki ani ve büyük değişimleri YSA'nın yakalayamamasıdır. YSA'ların yakınsadığı fonksiyonların yakınsama başarımı tüm veri kümesi için Şekil 7'de mavi gerçek fonksiyonu, kırmızı YSA yakınsama sonucunu göstermek üzere verilmektedir. 
Şekil 7'deki yakınsama sonuçları incelendiğinde 20 farklı yörüngeye ait veri setinden 4. (1073 no'lu

Tablo 3. YSA yakınsama sonuçları

\begin{tabular}{ccc}
\hline YSA numarası & Yakınsadı̆̆ fonksiyon & Ortalama karesel hata (MSE) \\
\hline 1 & $-\left(\hat{L}_{s}^{+} \cdot e\right)_{v_{x}}$ & 0.011 \\
2 & $-\left(\hat{L}_{s}^{+} \cdot e\right)_{v_{y}}$ & 1.0313 \\
3 & $-\left(\hat{L}_{s}^{+} \cdot e\right)_{v_{z}}$ & 60.4476 \\
4 & $-\left(\hat{L}_{s}^{+} \cdot e\right)_{\omega_{x}}$ & 0.0786 \\
5 & $-\left(\hat{L}_{s}^{+} \cdot e\right)_{\omega_{y}}$ & 24.9105 \\
6 & $-\left(\hat{L}_{s}^{+} \cdot e\right)_{\omega_{z}}$ & 0.4007 \\
\hline
\end{tabular}

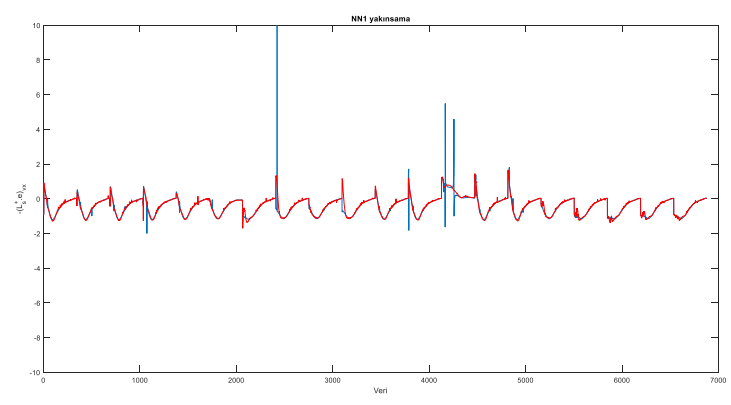

(a)

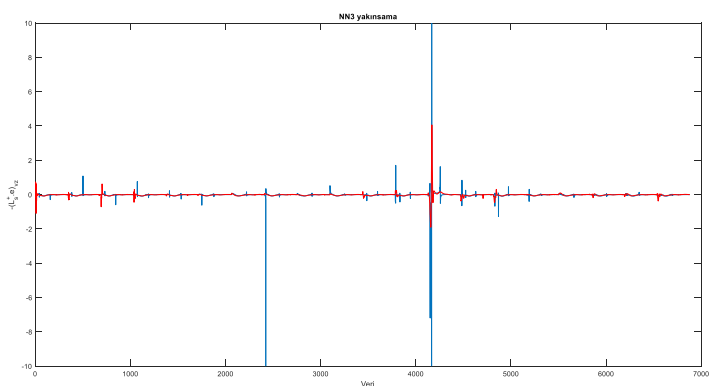

(c)

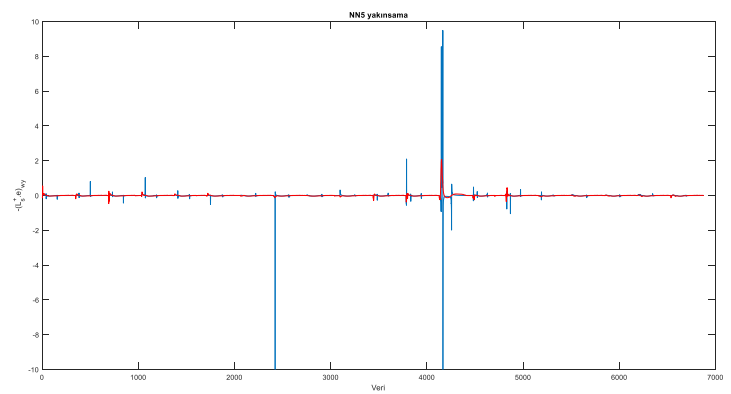

(e)

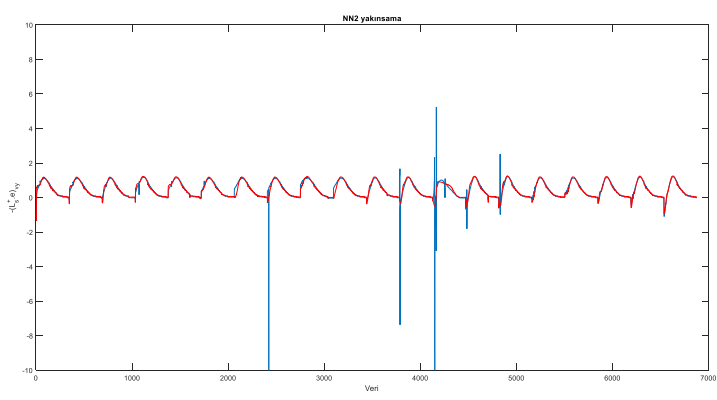

(b)

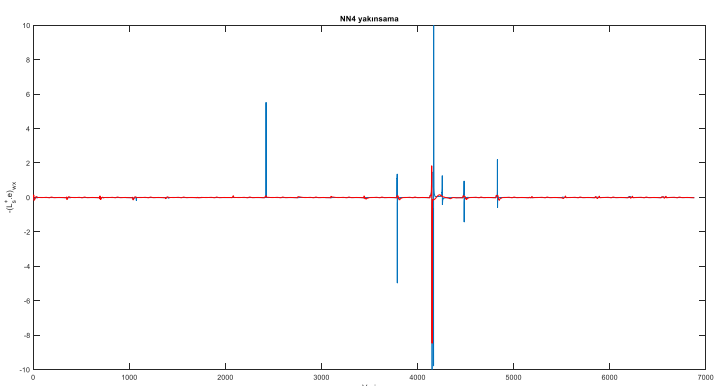

(d)

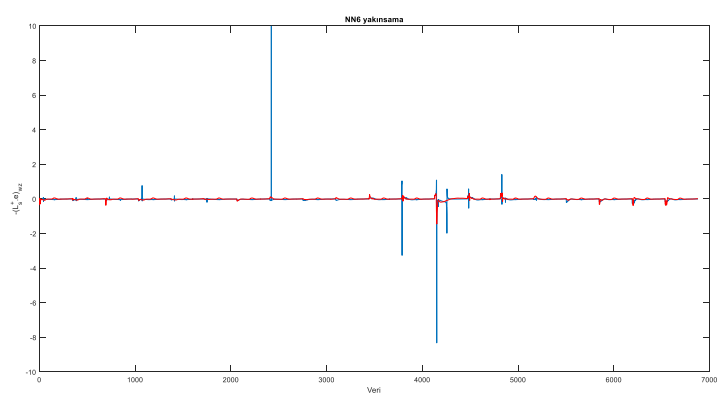

(f)

Şekil 7. YSA yakınsama sonuçları 


$$
\begin{aligned}
& \text { (a) YSA } 1 \rightarrow-\left(\hat{L}_{s}^{+} \cdot e\right)_{v_{x}} \text { (b) YSA2 } \rightarrow-\left(\hat{L}_{s}^{+} \cdot e\right)_{v_{y}} \text { (c) YSA3 } \rightarrow-\left(\hat{L}_{s}^{+} \cdot e\right)_{v_{z}} \\
& \text { (d) YSA4 } \rightarrow-\left(\hat{L}_{s}^{+} \cdot e\right)_{\omega_{x}} \text { (e) YSA5 } \rightarrow-\left(\hat{L}_{s}^{+} \cdot e\right)_{\omega_{y}} \text { (f) YSA6 } \rightarrow-\left(\hat{L}_{s}^{+} \cdot e\right)_{\omega_{z}}
\end{aligned}
$$

örnek), 8. (2423 no'lu örnek) ve 13. (4167 no'lu örnek) örnek setlerindeki yüksek fonksiyon değerleri göze çarpmaktadır. $\mathrm{Bu}$ yüksek fonksiyon değerlerinin kaynağı etkileşim matrisinin yalancı tersine dair ani değişimlerdir. Buna rağmen 6 YSA bu yüksek değerlere yakınsamaya çalıştığı Şekil 7.c-d-e'de görülmektedir. Daha önce de belirtildiği üzere Tablo 3 'teki yüksek MSE değerlerinin kaynağı bu noktadaki yüksek yakınsama hatalarıdır.

İkinci yakınsayıcı olarak kullanılan RTA, iki katmanlı bir yapı olup birinci katmanında radyal tabanlı fonksiyon adı verilen $e^{-\left(x^{2}\right)}$ fonksiyonu ile tanımlı fonksiyonlardan oluşan bir gizli katmanı ve doğrusal çıkış veren bir çıkış katmanı bulunmaktadır. RTA için MATLAB Neural Network Toolbox’ta iki seçenek bulunmaktadır. Birinci seçenekte veri sayısı kadar radyal fonksiyonlu nöron bulunduran RTA yapısı tanımlanırken ikinci yapıda verilen hedef MSE değerine göre ilk katmana radyal tabanlı nöron ekleyerek ilerleyen RTA yapısı bulunmaktadır. İkinci yapı daha az nöron kullanması sayesinde işlem yükünü kademeli olarak artırsa da işlem gücünün gelişmesiyle birlikte bu sorun ortadan kalkmıştır. Buna göre kullanılan birinci

Tablo 4. RTA yakınsama sonuçları

\begin{tabular}{ccc}
\hline RTA numarası & Yakınsadığı fonksiyon & Ortalama karesel hata (MSE) \\
\hline 1 & $-\left(\hat{L}_{s}^{+} \cdot e\right)_{v_{x}}$ & $1.7620 \mathrm{e}-20$ \\
2 & $-\left(\hat{L}_{s}^{+} \cdot e\right)_{v_{y}}$ & $2.2986 \mathrm{e}-20$ \\
3 & $-\left(\hat{L}_{s}^{+} \cdot e\right)_{v_{z}}$ & $1.3572 \mathrm{e}-21$ \\
4 & $-\left(\hat{L}_{s}^{+} \cdot e\right)_{\omega_{x}}$ & $5.6293 \mathrm{e}-21$ \\
5 & $-\left(\hat{L}_{s}^{+} \cdot e\right)_{\omega_{y}}$ & $6.6660 \mathrm{e}-21$ \\
6 & $-\left(\hat{L}_{s}^{+} \cdot e\right)_{\omega_{z}}$ & $1.0044 \mathrm{e}-21$ \\
\hline
\end{tabular}

seçenekteki RTA'da ilk katmanda 6880 nöron $(20 \times 344)$ bulunmaktadır. Hata hedefi olarak sifir olarak elde edilen ortalama karesel hata (MSE) değerleri Tablo 4'te verilmiştir.

Tablo 4'teki sonuçlar RTA'ların girişle tam bir uyum içinde olduğunu göstermektedir. Elde edilen grafiklerde yakınsanan fonksiyon ile hiçbir fark görülmediğinden sadece örnek olması açısından birinci fonksiyona dair yakınsama Şekil 8'de verilmiştir. Burada mavi gerçek fonksiyonu, kırmızı RTA yakınsama sonucunu göstermektedir. 


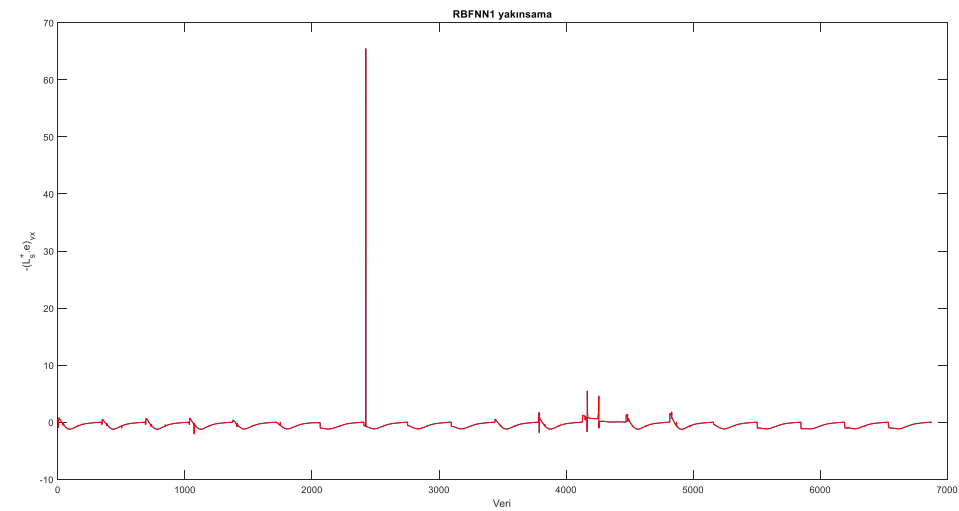

Şekil 8. $-\left(\widehat{L}_{s}^{+} \cdot e\right)_{v_{x}}$ veri setine ait RTA yakınsama sonucu

Burada her ne kadar RTA'nın YSA'dan çok daha fazla parametreyle iyi yakınsama sonuçları verdiği söylense de YSA'nın bozuculara karşıda RTA'ya göre daha gürbüz sonuçlar vereceği beklentisinin de literatürde verildiği belirtilmelidir. Ayrıca RTA’daki nöron sayısı fazlalığı çok yüksek hesapsal yüke sebep olmaktadır.

Üçüncü yakınsayıcı olarak kullanılan ve YSA ailesinin son üyelerinden olan EÖM tek gizli katmanlı YSA yapısındadır ve gizli katmanının parametrelerinde ayarlamaya ihtiyaç duymamaktadır [27]. Ayrıca tek aşamalı öğrenme adımıyla hesapsal yükü oldukça indirgenmiştir. Akıllı yakınsama için tek çıkışlı yapısı sebebiyle 1000 nörona sahip 6 farklı EÖM eğitim için kullanılmış ve yakınsama sonuçları Tablo 5 'te verilmiştir. EÖM'lar fonksiyon yakınsama için 0-1 arası çıkış verebildiklerinden giriş eğitim veri kümesi normalize edildikten sonra eğitim için kullanılmıştır. EÖM'ın yakınsadıkları fonksiyonlara dair sonuçlar ise Şekil 9'da verilmiştir.

Tablo 5. EÖM yakınsama sonuçları

\begin{tabular}{ccc}
\hline EÖM numarası & Yakınsadı̆̆ fonksiyon & Ortalama karesel hata (MSE) \\
\hline 1 & $-\left(\hat{L}_{s}^{+} \cdot e\right)_{v_{x}}$ & $1.1664 \mathrm{e}-04$ \\
2 & $-\left(\hat{L}_{s}^{+} \cdot e\right)_{v_{y}}$ & $1.1236 \mathrm{e}-04$ \\
3 & $-\left(\hat{L}_{s}^{+} \cdot e\right)_{v_{z}}$ & $1.1025 \mathrm{e}-04$ \\
4 & $-\left(\hat{L}_{s}^{+} \cdot e\right)_{\omega_{x}}$ & $7.7440 \mathrm{e}-05$ \\
5 & $-\left(\hat{L}_{s}^{+} \cdot e\right)_{\omega_{y}}$ & $1.1449 \mathrm{e}-04$ \\
6 & $-\left(\hat{L}_{s}^{+} \cdot e\right)_{\omega_{z}}$ & $9.0250 \mathrm{e}-05$ \\
\hline
\end{tabular}




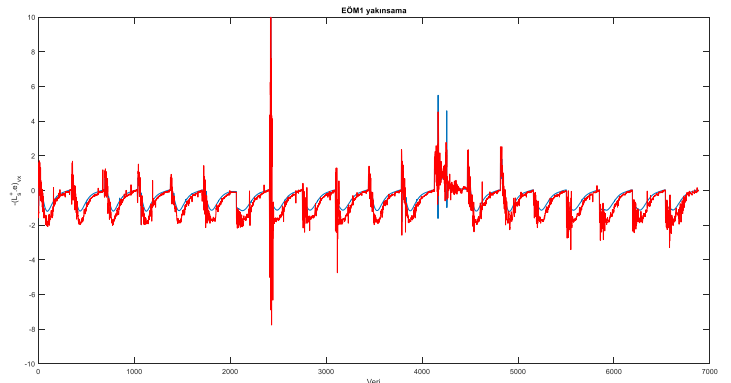

(a)

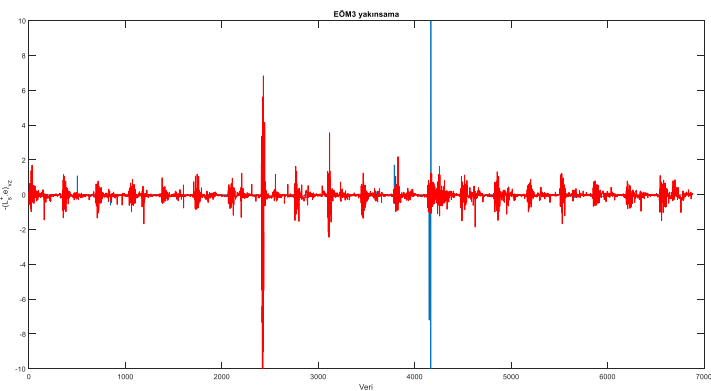

(c)

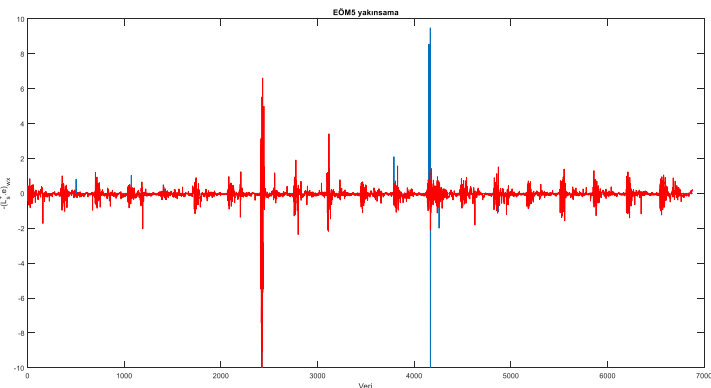

(e)

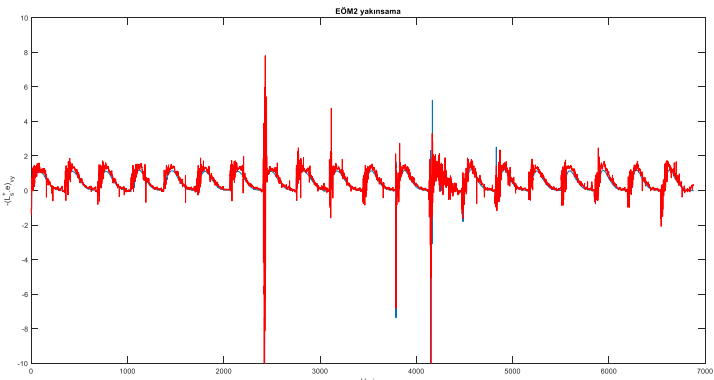

(b)

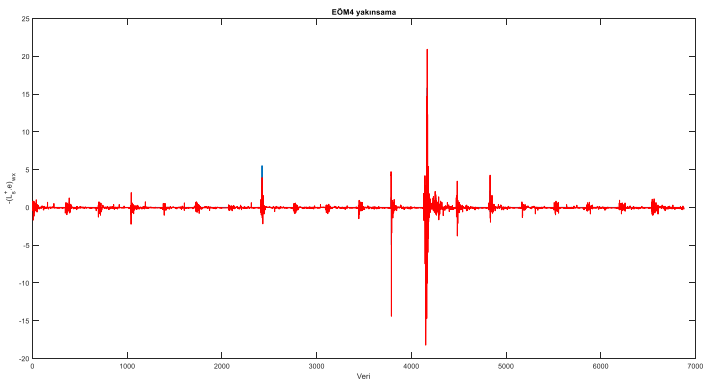

(d)

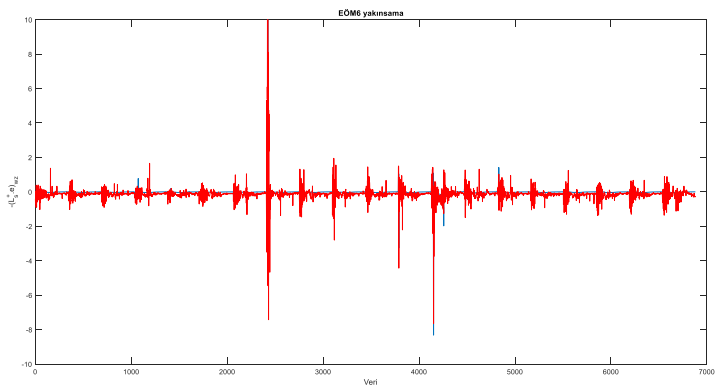

(f)

Şekil 9. EÖM yakınsama sonuçları
(a) EÖM1 $\rightarrow-\left(\hat{L}_{s}^{+} \cdot e\right)_{v_{x}}$ (b) EÖM2 $\rightarrow-\left(\hat{L}_{s}^{+} \cdot e\right)_{v_{y}}$ (c) EÖM3 $\rightarrow-\left(\hat{L}_{s}^{+} \cdot e\right)_{v_{z}}$
$(\mathrm{d})$ EÖM4 $\rightarrow-\left(\hat{L}_{s}^{+} \cdot e\right)_{\omega_{x}}(\mathrm{e}) \mathrm{EÖM} \rightarrow-\left(\hat{L}_{s}^{+} \cdot e\right)_{\omega_{y}}(\mathrm{f}) \mathrm{EÖM} 6 \rightarrow-\left(\hat{L}_{s}^{+} \cdot e\right)_{\omega_{z}}$

Şekil 9'daki EÖM yakınsama sonuçları ve Tablo 5'teki MSE değerleri incelendiğinde her ne kadar başarımın yüksek olduğu görülse de EÖM'nin getirdiği ani değişimler göze çarpmaktadır. Bu ani değişimlerin de tıpkı etkileşim matrisinin yalancı tersinin getirdiği yüksek hızlar problemini getireceği aşikardır.

Önerilen yakınsayıcılar GTGS sistemi üzerinde denendiğinde YSA ve EÖM yakınsayıcıların her ne kadar başarımları yüksek olsa da GTGS sisteminde öznitelikleri görüntü dışına çıkararak ıraksamaya sebep oldukları yapılan deneyler sonucunda görülmüştür. RTA yakınsayıcı ise tıpkı klasik GTGS gibi sonuç vermekte ve aynı başarımı yakalamaktadır. RTA sonuçları aynı olduğundan deneysel sonuçlara tekrar yer verilmemiştir.

Önerilen sistemin ikinci aşaması için farklı kazanç değerlerinde klasik GTGS davranışları incelendiğinde $(0.3 \leq \lambda \leq 0.8)$ düşük kazanç değerlerinde düşük hız profilleriyle beraber yakınsama iterasyon sayısının 500’lere kadar çıktığı görülmektedir. Yüksek kazanç değerlerinde ise her ne kadar iterasyon sayısında düşüş olsa da robot manipülatörün uç işlevci hız limiti olarak kabul edilen $\pm 1 \mathrm{~m} / \mathrm{s}-\mathrm{rad} / \mathrm{s}$ değerlerinin özellikle $v_{x}, v_{y}$ doğrusal hızlarında aşıldığı gözlemlenmiştir. Aynı değerlerde hareketlilik incelendiğinde doğası gereği düşük $M$ değerlerinde robotun tekillik koşullarına yakın olduğu, bu sebeple robot hızlarının düşürülmesi 
gerektiği gözlemlenmiştir. Yani hareketlilik düşükse kazanç değeri düşürülmelidir. $M$ değerinin yapılan deneylerde 0-0.03 aralığında değiştiği gözlemlenmiştir.

Farklı kazanç değerleri için klasik GTGS davranışları göz önünde bulundurularak 3 girişli ( $\|e\|, d\|e\| / d t$, M) bir BM yapısı MATLAB Fuzzy Logic Toolbox kullanılarak oluşturulmuştur. Değişken kazanç için kullanılan BM birimi Mamdani tipindedir ve çıkış, üyelik işlevleri cinsinden tanımlanmıştır. Birleştirme yöntemi olarak maksimum, durulaştırma yöntemi olarak ağırlık merkezi yöntemi kullanılmıştır. Girişlere ve çıkışa dair üyelik işlev tipi olarak gauss ve genelleştirilmiş çan kullanılmıştır. $\|e\|$ ve $d\|e\| / d t$ değerleri bulanık mantık birimine normalize edilerek uygulanmıştır. $\mathrm{Bu}$ normalizasyonda hata normu 700, hata türev normu 15 ile sınırlandırılmıştır. $\|e\|$ ve $d\|e\| / d t$ için Düşük-Orta-Yüksek olmak üzere 3 üyelik işlevi ve $M$ için DüşükYüksek olmak üzere iki üyelik işlevi tanımlanmıştır. $\lambda$ için çıkış üyelik işlevi olarak Düşük-Orta-Yüksek olmak üzere 3 üyelik işlevi kullanılmıştır. Girişlere ve çıkışa dair üyelik işlevleri Şekil 10’da gösterilmiştir.

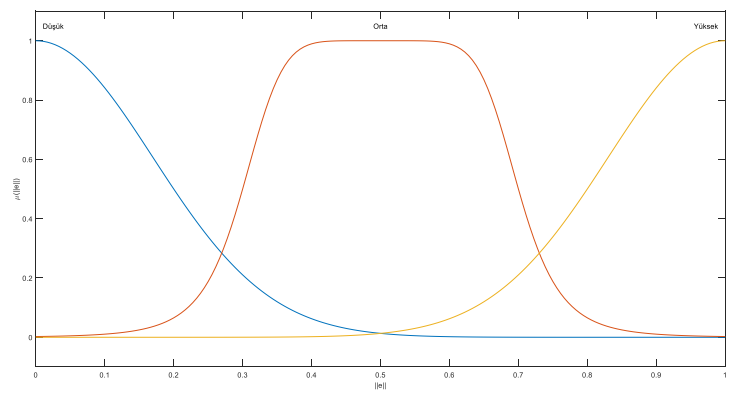

(a)

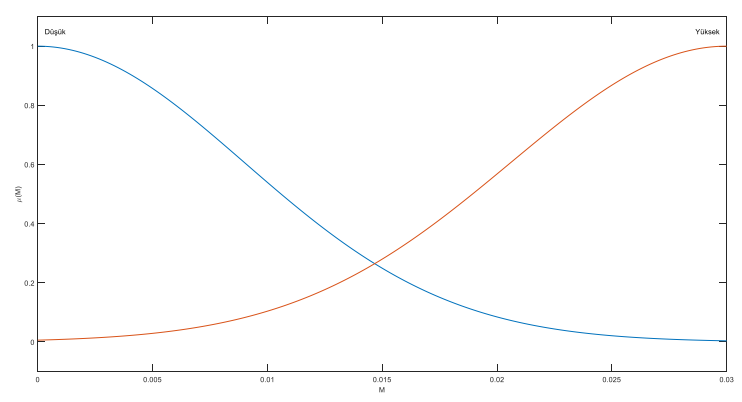

(c)

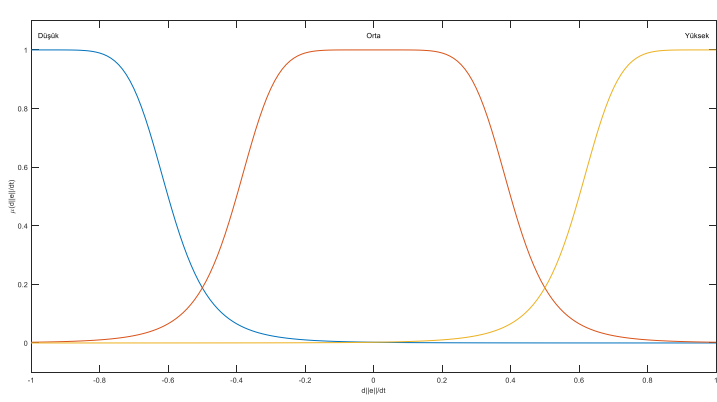

(b)

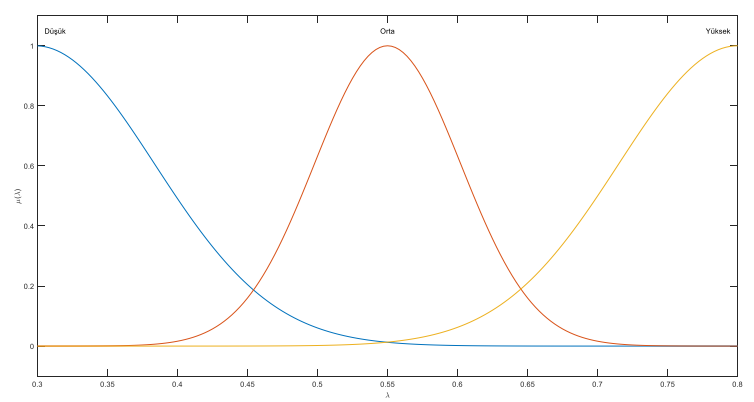

(d)

Şekil 10. Değişken kazanç BM biriminin üyelik işlevleri

(a) $\mu(\|e\|)$ (b) $\mu(d\|e\| / d t)$ (c) $\mu(M)$ (d) $\mu(\lambda)$

Farklı kazanç değerleriyle klasik GTGS deneyleri sonucunda elde edilen bulgular ve gözlemler sonucu oluşturulmuş BM kural tablosu Tablo 6'da verilmiştir. Şekil 10'daki üyelik işlevleri ve Tablo 6'daki kural tablosuyla BM biriminin giriş-çıkış yüzeyi $\|e\|$ ve $d\|e\| / d t$ 'ye karşılık $\lambda$ için Şekil 11 'de verilmiştir.

Senaryo olarak karşılaştırma açısından (4) ve (5) hedef öznitelikler ve eklem başlangıç koşulları seçilmiştir. Bu senaryo ile elde edilen 3B uç işlevci hızları Şekil 12.a'da, öznitelik hataları şekil 12.b'de, değişken kazancın değişimi Şekil 12.c'de ve hareketliliğin klasik GTGS ile karşılaştırması Şekil 12.d'de verilmiştir.

Şekil 12.c incelendiğinde $\lambda_{a}$ 'nın BM biriminin Şekil 10'teki üyelik işlevlerine ve Tablo 6'daki kural tabanına göre değişimi gözlemlenmektedir. $\mathrm{Bu}$ değişimde 0-50 iterasyon arası hızlı değişimler göze çarpmaktadır. Bu hızlı değişimin sebebi hata türev normundaki ani değişimlerdir. Bu ani kazanç değişimlerinin etkileri Şekil 12.b'deki hatalarda ve Şekil 12.a'daki özellikle $v_{x}$ sinyalinde açıkça görülmektedir. 
Yakınsama iterasyon sayısı göz önünde bulundurulduğunda ise Şekil 6.e'deki klasik GTGS sistemine dair hatalar ve Şekil 12.b'deki hatalar incelendiğinde klasik GTGS sistemine ait hata normunun 16 pikselin altına 288. iterasyonda indiği görülürken değiş̧ken kazançlı GTGS sisteminin 215. iterasyonda indiği

Tablo 7. Değişken kazanç BM birimi kural tablosu

\begin{tabular}{|c|c|c|c|}
\hline Giriş $\|e\|$ & Giriş $d\|e\| / d t$ & Giriş $M$ & Çıkış $\lambda$ \\
\hline DÜŞÜK & DÜŞÜK & DÜŞÜK & YÜKSEK \\
\hline DÜŞÜK & DÜŞÜK & YÜKSEK & YÜKSEK \\
\hline DÜşÜK & ORTA & DÜŞÜK & YÜKSEK \\
\hline DÜŞÜK & ORTA & YÜKSEK & YÜKSEK \\
\hline DÜŞÜK & YÜKSEK & DÜŞÜK & ORTA \\
\hline DÜŞÜK & YÜKSEK & YÜKSEK & YÜKSEK \\
\hline ORTA & DÜŞÜK & DÜŞÜK & ORTA \\
\hline ORTA & DÜŞÜK & YÜKSEK & YÜKSEK \\
\hline ORTA & ORTA & DÜŞÜK & ORTA \\
\hline ORTA & ORTA & YÜKSEK & ORTA \\
\hline ORTA & YÜKSEK & DÜŞÜK & DÜşÜK \\
\hline ORTA & YÜKSEK & YÜKSEK & ORTA \\
\hline YÜKSEK & DÜŞÜK & DÜŞÜK & ORTA \\
\hline YÜKSEK & DÜŞÜK & YÜKSEK & ORTA \\
\hline YÜKSEK & ORTA & DÜŞÜK & ORTA \\
\hline YÜKSEK & ORTA & YÜKSEK & ORTA \\
\hline YÜKSEK & YÜKSEK & DÜȘÜK & DÜŞÜK \\
\hline YÜKSEK & YÜKSEK & YÜKSEK & DÜȘÜK \\
\hline
\end{tabular}




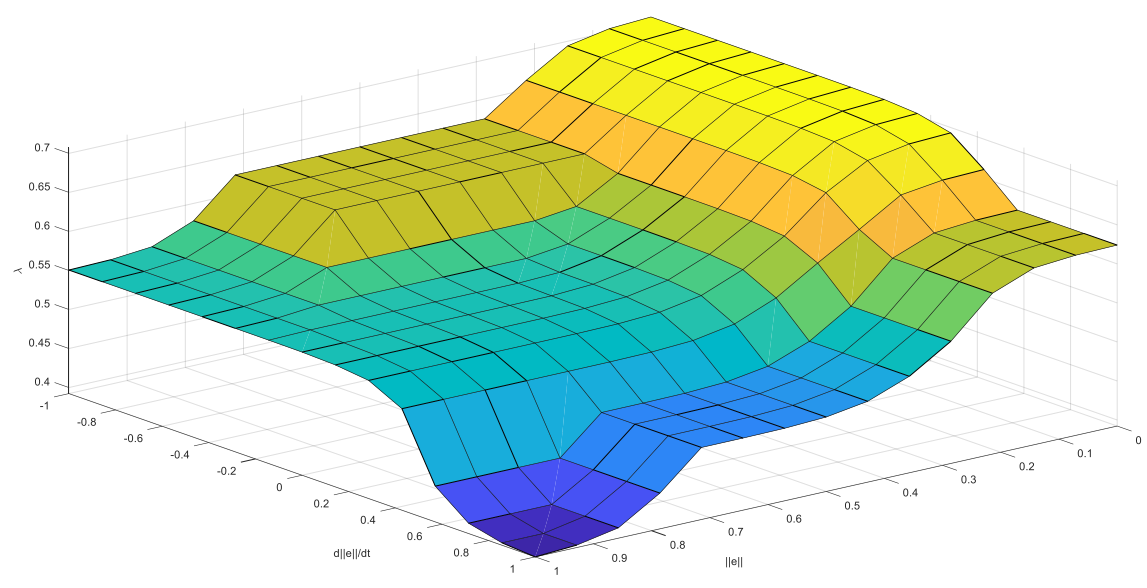

Şekil 11. Değişken kazanç BM biriminin giriş-çıkış yüzeyi

görülmektedir. $\mathrm{Bu}$ açıdan karşılaştıııldı̆̆ı̆nda önerilen GTGS sistemi yaklaşık \%25.35 daha hılı yakınsamaktadır. Bu hızlı yakınsamayla beraber Şekil 6.d klasik GTGS sistemine dair hızlar ve Şekil 12.a'daki hızlar incelendiğinde ise hız değerlerinde büyük artışların olmadığı ve hız limitleri içerisinde kalındığı görülmektedir. Böylece önerilen sistemle hız limitleri içinde daha hızlı yakınsama sağlandığı söylenebilmektedir.

Şekil 12.d'de ise klasik GTGS sistemine ve BM tabanlı değişken kazançlı sisteme dair hareketlilik sonuçları verilmiştir. Bu sonuçlar incelendiğinde önerilen sisteme dair hareketlilik değiş̧iminin klasik GTGS sistemi ile neredeyse aynı kaldığı ve bir üstünlük sağlanamadığı, hatta 150-180 iterasyon aralığında klasik GTGS sisteminin daha üstün kaldığı görülmektedir. Buradan yola çıkarak önerilen sistemin hareketlilik açısından sisteme bir kazanç sağlayamadığı söylenebilmektedir.

Önerilen sistemin üçüncü aşamasında yaklaşılan görüntü sınırına zıt yönde bir hareket ile öznitelikleri görüş alanı içinde tutma yaklaşımı önerilmiştir. Bu zıt yönlü hareket için tanımlanacak hız değeri de önerilen sistemde BM kullanılarak tanımlanmıştır. Bölüm II'de yapılan üç bölge tanımlamalarıyla 1280×960 çözünürlüklü görüntüde bölge sınırları aşağıdaki gibi belirlenmiştir:

$$
\text { Bölge Tipi }(u, v)=\left\{\begin{array}{cc}
\text { Bölge A } & \text { eğer } u<1050 \& v<825 \\
\text { Bölge B } & \text { eğer } 1050 \leq u<1200 \| 825 \leq v<900 \\
\text { Bölge C } & \text { eğer } u \geq 1200 \| v \geq 900
\end{array}\right.
$$

İlk olarak tanımlı Bölge B ve C'ye giren öznitelikleri güvenli sayılan Bölge A'ya doğru sürüklemek için manuel denemeler yapılmıştır. Bu denemelerde $u$ yönünde Bölge A'yı terk eden öznitelikler için zıt yönlü $\max \left(v_{x}^{F O V}\right)=0.1 \mathrm{~m} / \mathrm{s}$ maksimum değerli bir hız ve $v$ yönünde Bölge A'yı terk eden öznitelikler için zıt yönlü $\max \left(v_{x}^{F O V}\right)=0.1 \mathrm{~m} / \mathrm{s}$ maksimum değerli bir hız tanımlamasının yeterli olduğu görülmüşstür. Bu tanımlamalarla görüş alanı koruma için yeni tanımlanan uç işlevci hızları aşağıdaki gibidir:

$$
\begin{aligned}
& v_{x}^{\prime}=v_{x}-v_{x}^{F O V} \\
& v_{y}^{\prime}=v_{y}-v_{y}^{F O V} \\
& v=\left[\begin{array}{lllllll}
v_{x}^{\prime} & v_{y}^{\prime} & v_{z} & \omega_{x} & \omega_{y} & \omega_{z}
\end{array}\right]^{T}
\end{aligned}
$$

Elde edilen maksimum zıt yönlü hızların Bölge B'de uygulanması sürekli bölge geçişine sebep olup hız işaretlerinde çatırtıya sebep olacağı aşikardır. Bunun yerine projede Bölge B'ye giren öznitelikler için tanımlanacak zıt yönlü hızlar birer BM birimiyle tanımlanmıştır. Bu BM birimleriyle (8)'deki hızlar şu şekilde tanımlanmıştır: 
$s_{i}^{\prime}=\left\{s_{i} \in \boldsymbol{s} \mid \max (s)\right\}, \forall i=1,2,3$
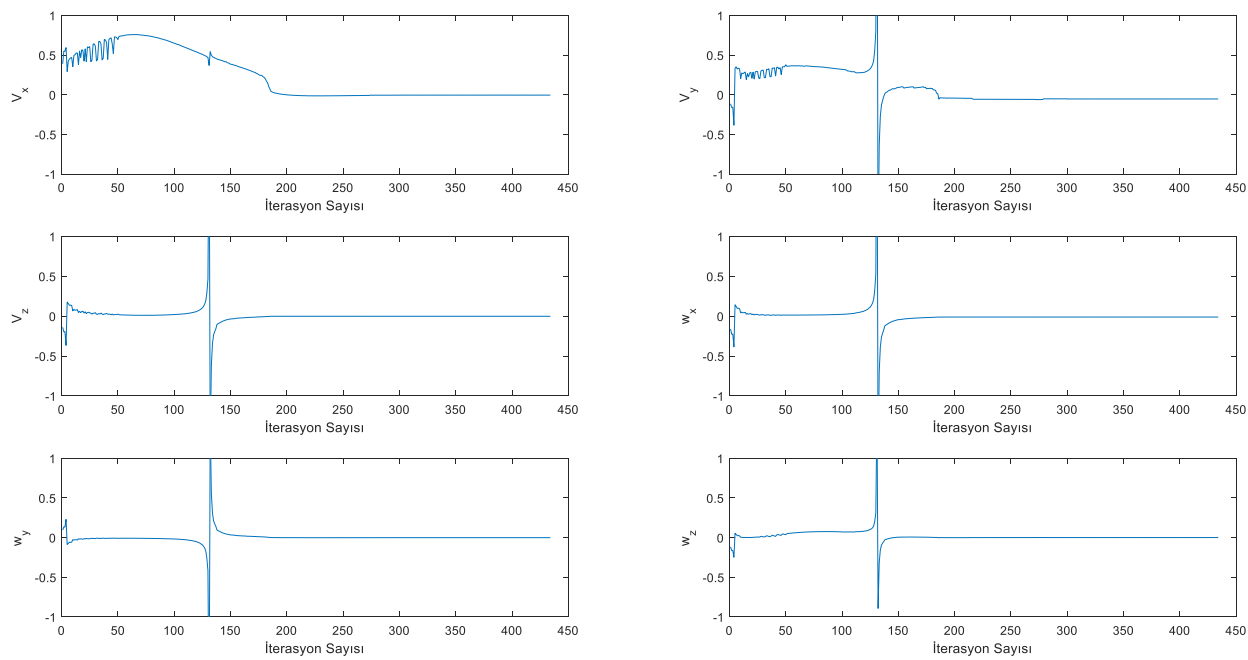

(a)

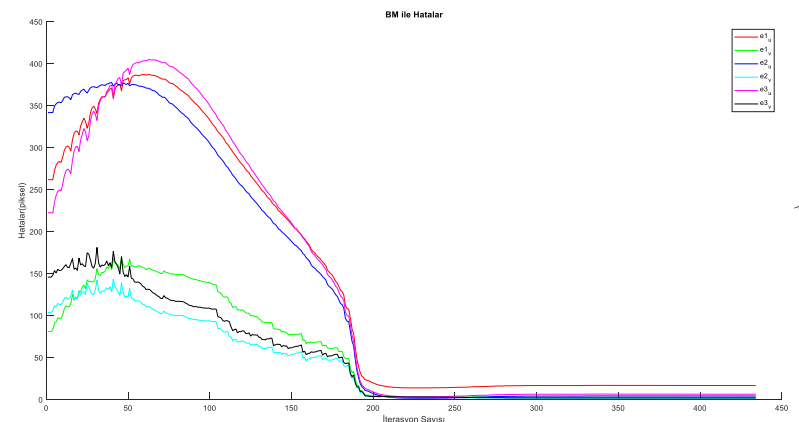

(b)

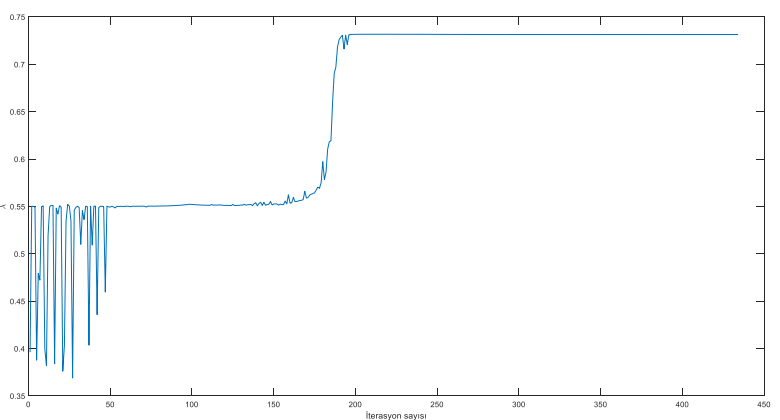

(c)

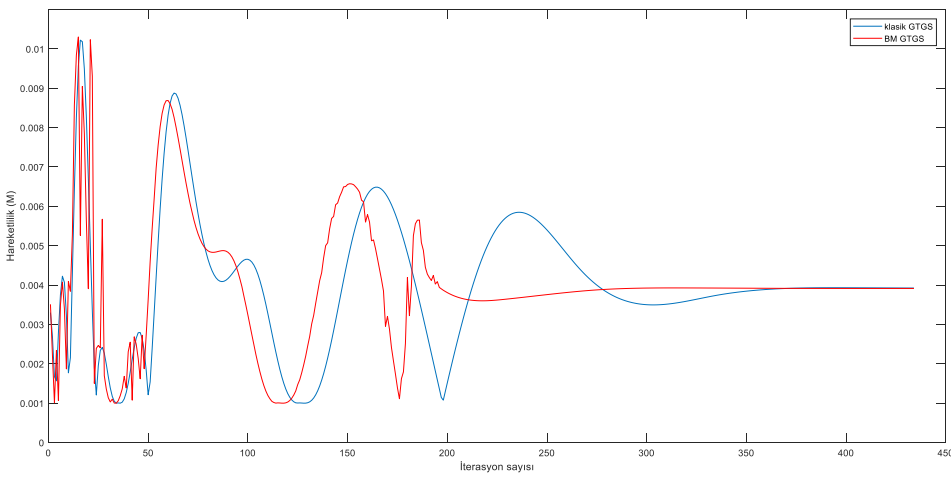

(d)

Şekil 12. BM kullanan değişken kazanç sonuçları

(a) Uç işlevci hızları (b) Öznitelik hataları (c) $\lambda$ (d) Hareketlilik 


$$
\begin{aligned}
& s_{i}^{\prime}\left(u_{i}, v_{i}\right) \in \text { Bölge } A \Rightarrow v_{x}^{F O V}=0, v_{y}^{F O V}=0 \\
& s_{i}^{\prime}\left(u_{i}, v_{i}\right) \in \text { Bölge } B \Rightarrow v_{x}^{F O V}=B M_{x}^{F O V}\left(u_{i}\right), v_{y}^{F O V}=B M_{y}^{F O V}\left(v_{i}\right) \\
& s_{i}^{\prime}\left(u_{i}, v_{i}\right) \in \text { Bölge } C \Rightarrow v_{x}^{F O V}=v_{x_{-} \max }^{F O V}, v_{y}^{F O V}=v_{y_{\_} \max }^{F O V}
\end{aligned}
$$

(10)'daki BM birimler Mamdani tipinde, giriş-çıkış üyelik işlevleri gauss şeklinde, durulaştırma yöntemi ağırlıklandırılmış ağırlık merkezi olarak seçilmiş, kural tabanlarıysa üç kural yumuşak hız geçişi sağlayacak şekilde tanımlanmıştır. BM birimlerinin üyelik işlevleri ve yüzeyleri Şekil 13 'te gösterilmiştir.

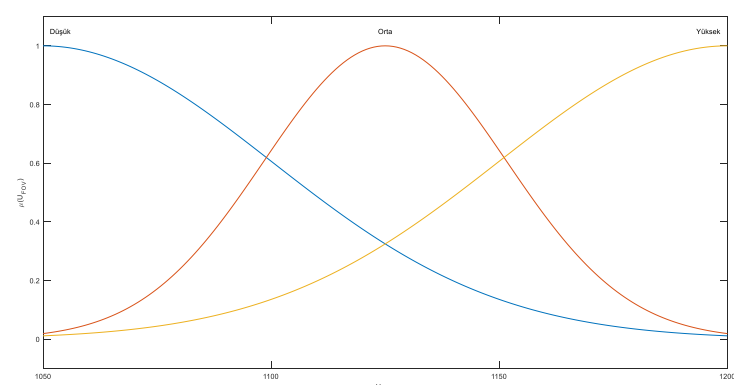

(a)

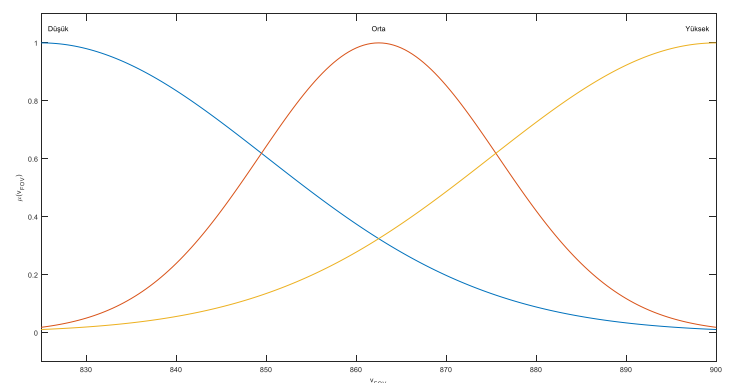

(c)

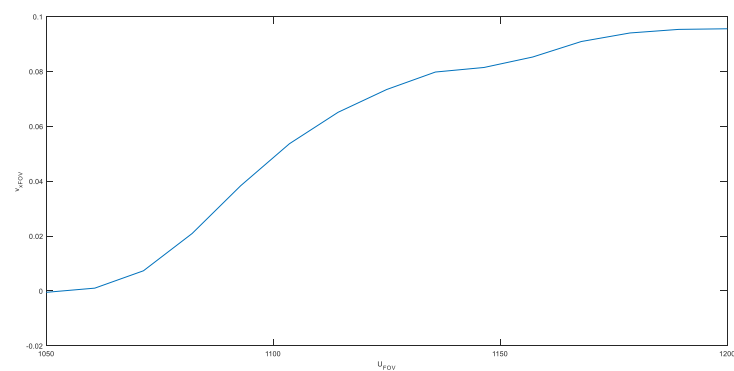

(e)

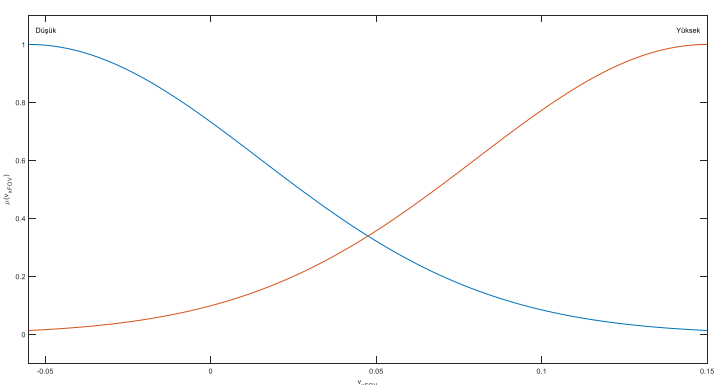

(b)

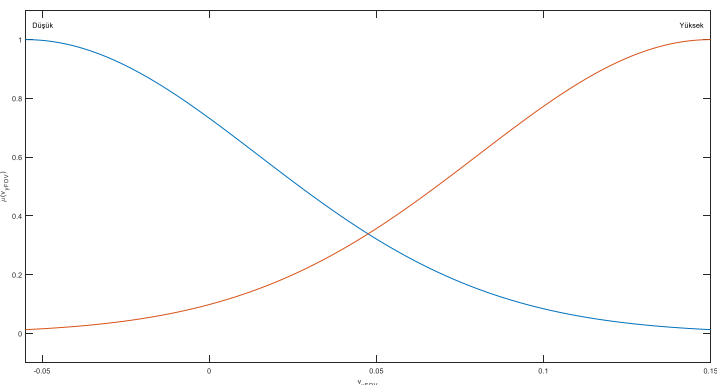

(d)

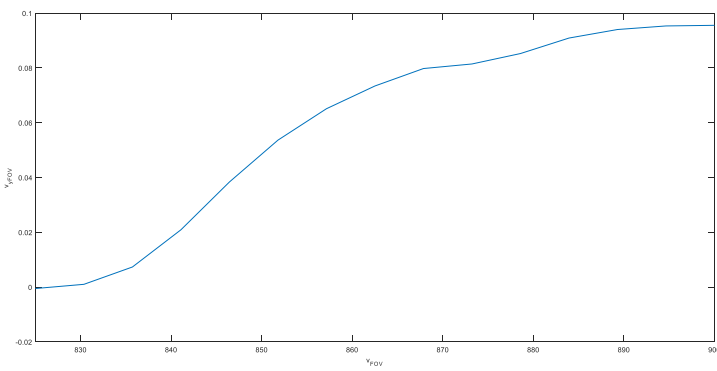

(f)

Şekil 13. Görüş alanı koruma için kullanılan BM birimleri

(a) $B M_{x}^{F O V}$ giriş üyelik işlevleri (b) $B M_{x}^{F O V}$ çıkış üyelik işlevleri (c) $B M_{y}^{F O V}$ giriş üyelik işlevleri

(d) $B M_{y}^{F O V}$ çıkış üyelik işlevleri (e) $B M_{x}^{F O V}$ giriş-çıkış yüzeyi (f) $B M_{y}^{F O V}$ giriş-çıkış yüzeyi

Görüş alanı korumayı göstermek için özniteliklerin Bölge B’ye geçtiği bir GTGS durumu ele alınmıştır. $\mathrm{Bu}$ GTGS durumunda, $s^{*}(u, v)$ (4)'teki gibi kalırken $q_{F O V}(0)$ başlangıç eklem açıları aşağıdaki gibi tanımlanmıştır:

$$
q_{F O V}(0)=\left[\begin{array}{llllll}
-20.3 & -23.1 & -71.4 & 2.2 & 66.5 & -83.9
\end{array}\right]^{\circ}
$$


Bu senaryo için başlangıç öznitelik durumları bölge gösterilimleriyle beraber Şekil 14'de, elde edilen uç işlevci 3B hızları, öznitelik hataları ve öznitelik yörüngeleri Şekil 15'te verilmiştir.

Şekil 15.a ve 15.b incelendiğinde özniteliklerin Bölge B'ye girdiği 49. iterasyondan itibaren görüş alanı için kullanılan $B M_{x}^{F O V}$ 'un devreye girdiği, hız ve hata sinyallerinde çatırtı oluştuğu görülmektedir. Bu çatırtının sebebi Şekil 15.c'de görüldüğü üzere öznitelikler Bölge B'deyken onları sürükleyen zıt yönlü hızın devreden çıkmasıyla GTGS sebebiyle özniteliklerin tekrar Bölge B’ye doğru yönelmesi ve tekrar $B M_{x}^{F O V}$ biriminin zit yönlü hız uygulamasıyla tekrar Bölge A'ya geçmesidir. Bu çatırtının yok edilmesi ve özniteliklerin Bölge B'ye girdiği anda sadece Bölge A-Bölge B hat çizgisinde kalmasını sağlamak için denemeler devam etmektedir.

Önerilen sistemle üç farklı GTGS problemine sunulan çözümlerin aynı anda beraber çalışabilirliği amaçlarındandır. Burada bu denemelerde değişken kazancın getirdiği ani ve büyük değişimler doğrultusunda

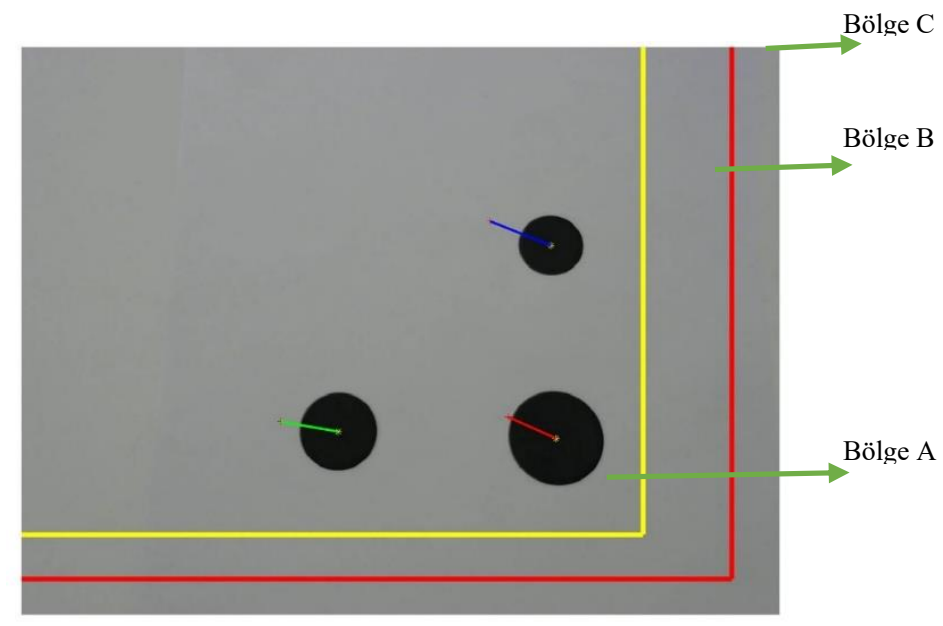

Şekil 14. Görüş alanı koruma örneği için başlangıç öznitelikleri ve bölgeler
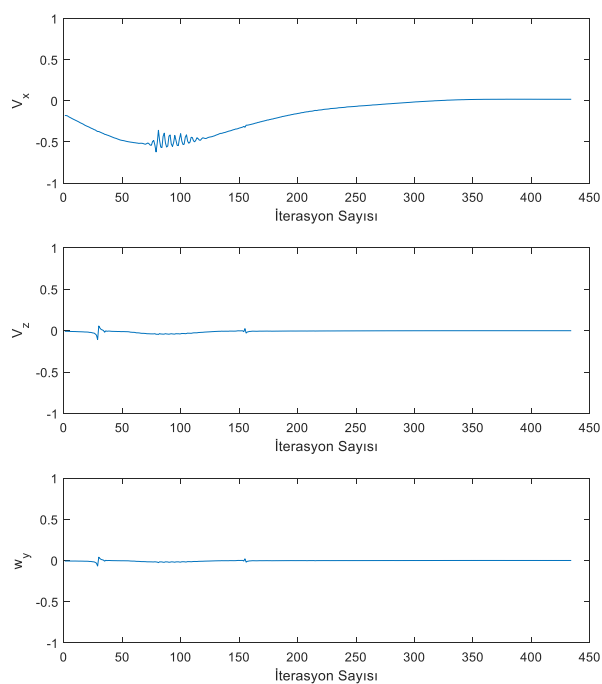
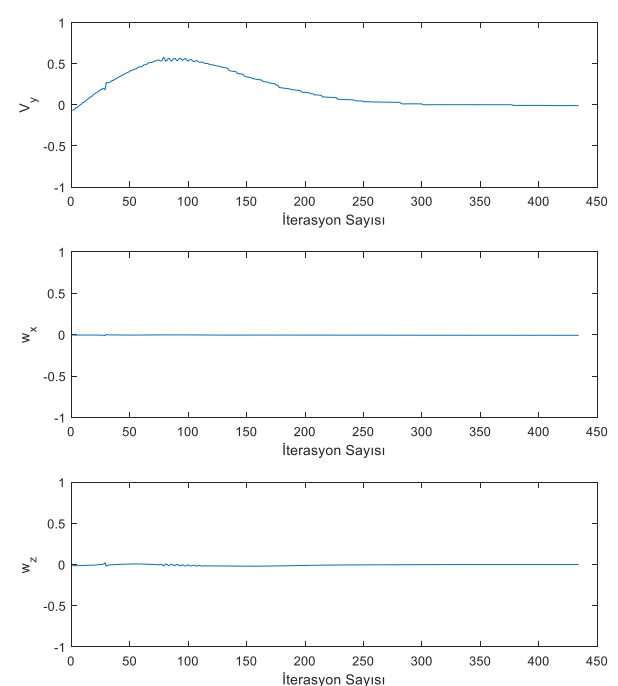

(a) 


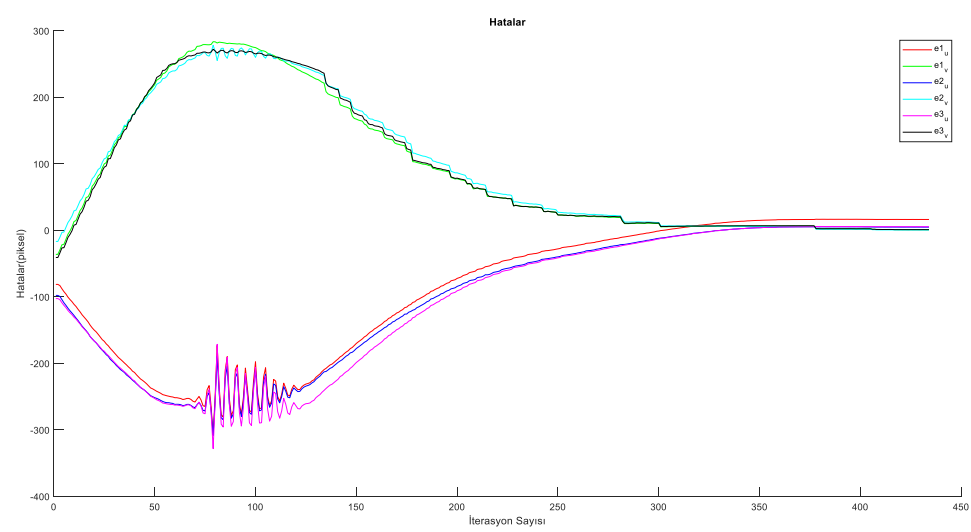

(b)

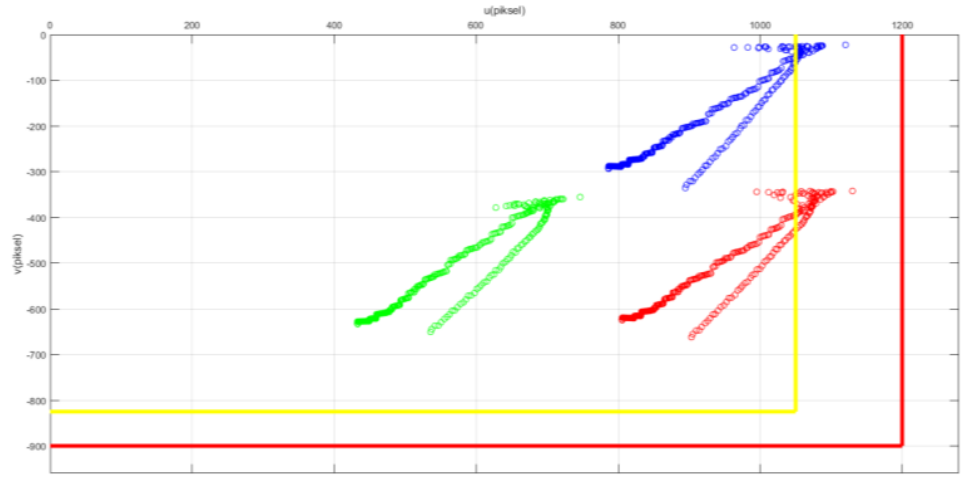

(c)

Şekil 15. Görüş alanı koruma örneği için sonuçlar

(a) Uç işlevci ait 3B hızlar hızları (b) Öznitelik hataları (c) Özniteliklerin yörüngeleri

yakınsayıcılar istenilen başarımı elde edememiş ve GTGS yakınsayamadan eldeki öznitelikler BM tabanlı görüş alanı korumasını da aşarak görüntü dışına çıkmışlardır. Burada özniteliklerin görüntü dışına çıkışları yine ani gelen değişimlere bağlı ani hız değişimlerinden ve BM biriminin oluşturduğu zıt yönlü hızların yeterli kalamamasındandir.

Önerilen sistemin görüntüye bağlı olarak özniteliklerde görülebilecek gürültülere karşı gürbüz olması önerilen sistemin amaçlarındandır. Bu amaç doğrultusunda önerilen sisteme literatürdeki çalışmalara benzer [28] her adım için rasgele 2 piksel öznitelik gürültüsü altında aynı başarımı elde edip etmediği denenmiştir. Burada, literatürdeki çalışmalara bakarak bu bozucu etkiler için analitik bir çıkarım yapılamayacağı, sadece deneysel çalışma ile gürbüzlüğü kanıtlanabileceği belirtilmelidir.

Senaryo olarak karşılaştırma açısından yine (4) ve (5) hedef öznitelikler ve eklem başlangıç koşulları seçilmiştir. Bu senaryo ile akıllı yakınsayıcıların hiçbiri yakınsama edemediğinden sadece BM tabanlı değişken kazancın devrede olduğu sonuçlar verilmiştir. Elde edilen öznitelik yörüngeleri Şekil 16.a'da, 3B uç işlevci hızları Şekil 16.b'da, değişken kazancın değişimi Şekil 16.c'de, öznitelik hataları Şekil 16.d'de verilmiştir.

Şekil 16 ve Şekil 12'deki sonuçlar karşılaştırıldığında öznitelik yörüngelerindeki ve hatalardaki değişimlerin değişen kazanç durumundakinden daha da fazla büyüdüğü açık bir şekilde görülmektedir. Rasgele gürültünün getirdiği bu değişimler Şekil 16.c'de değişken kazanç için de ani değişim, Şekil 16.b'deki hızlarda da çatırtı olarak ortaya çıkmaktadır. Devamında sistem yakınsamayı sağladığı 200. iterasyondan sonra da gürültünün etkilerinin devam ettiği Şekil 16.c'deki kazançta ve Şekil 16.d'deki öznitelik hatalarında açıkça görülmektedir. $\mathrm{Bu}$ çatırtılara rağmen önerilen GTGS sisteminin BM tabanlı değişken kazanç çözümünün öznitelik gürültülerine karşı gürbüzlüğü kanıtlanmış bulunmaktadır. 


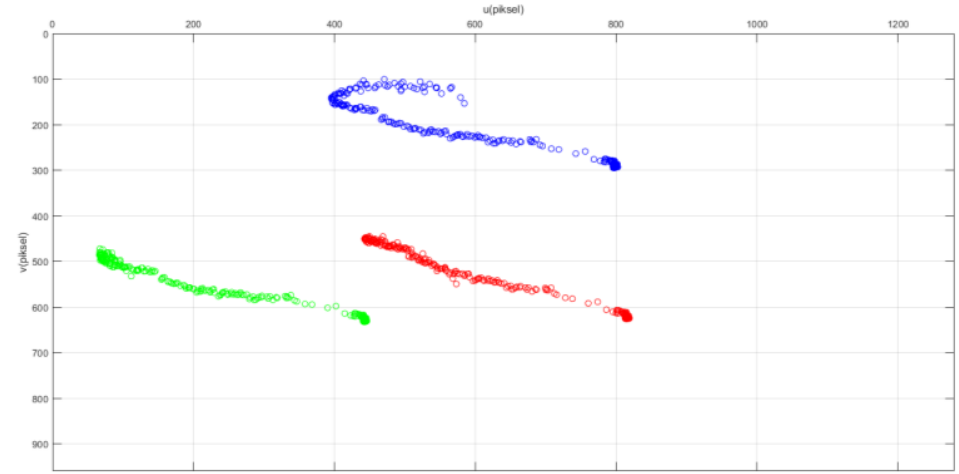

(a)
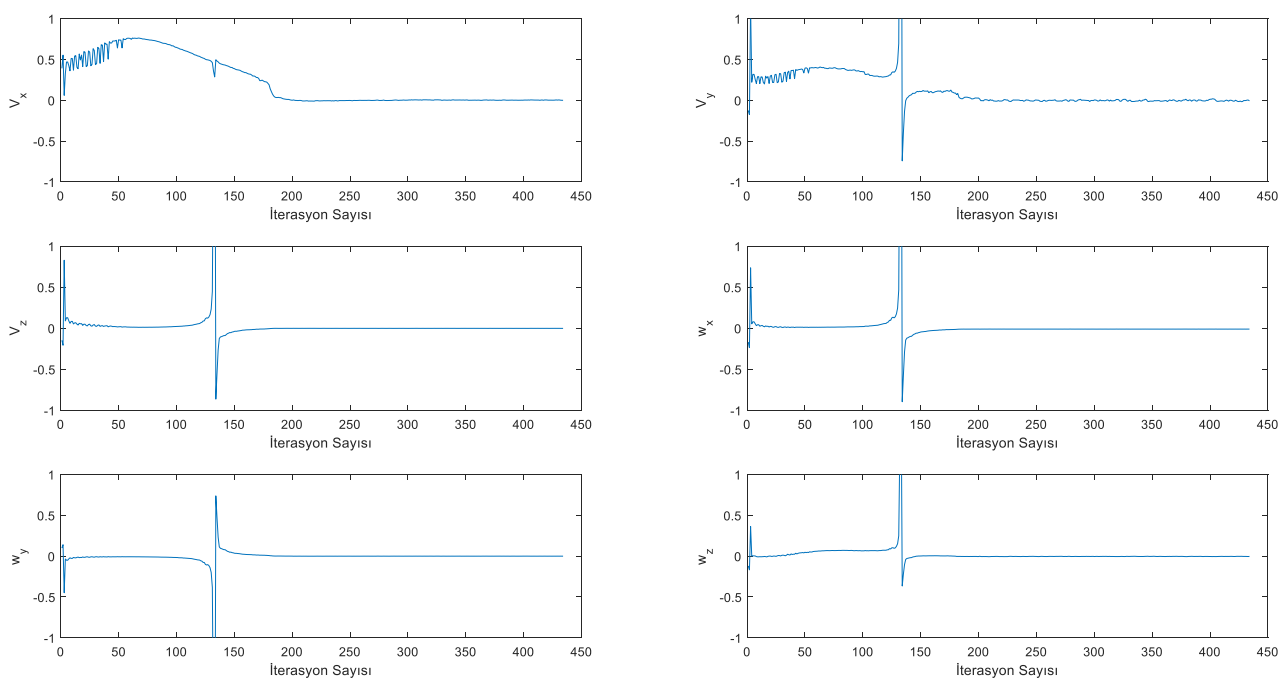

(b)

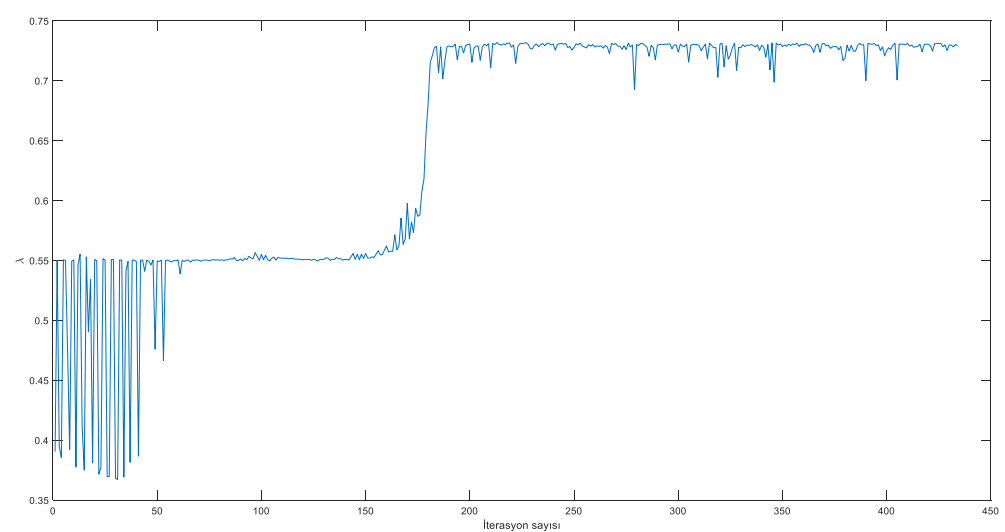

(c) 


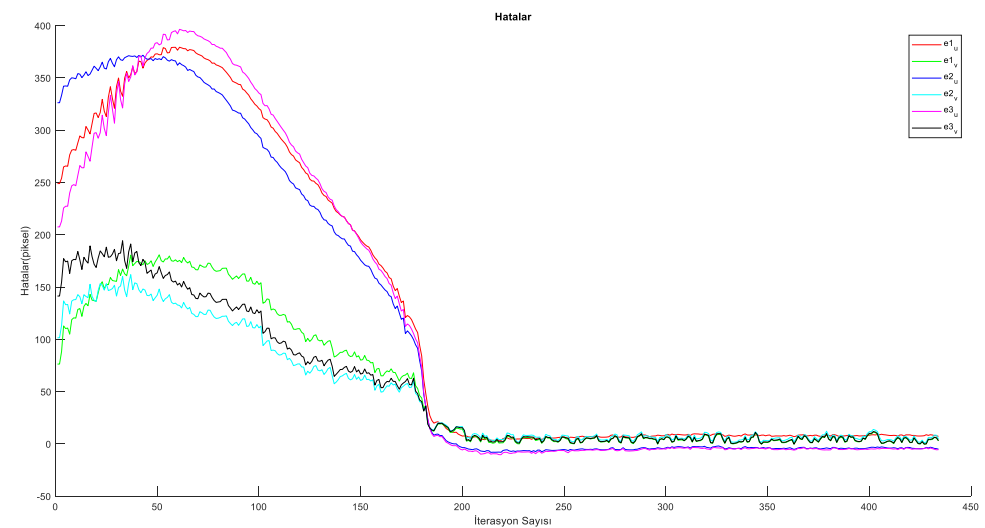

(d)

Şekil 16. Öznitelik gürültüsünde BM kullanan değişken kazanç sonuçları

(a) Öznitelik yörüngeleri (b) Uç işlevci hızları (c) Değişken kazanç (d) Öznitelik hataları

\section{SONUÇLAR VE GELECEK ÇALIŞMALAR}

Endüstriyel robot manipülatörlerin görsel geribeslemeli uygulamalarında GTGS duruş kestirimi gerektirmediğinden robot manipülatörler için popüler GS yaklaşımlarından biridir. GTGS tabanlı yenilikçi yaklaşımlar kontrolcü tasarımı ve kararlılık analizi gibi teorik sorunlara odaklanmanın yanında gerçekleme sırasındaki sorunlara da çözüm üretmek zorundadır. Bu gerçekleme sorunlarından temel üç tanesi sırasıyla etkileşim matrisinin tersinin eldesi, kontrolör için uygun bir sabit kazanç değerinin tanımlanması ve özniteliklerin görüş alanı içinde tutulmasıdır. GTGS için etkileşim matrisi her ne kadar yalancı tersi ile beraber kullanılsa da tekilliklerin oluşması durumunda kontrol yasası işleyememektedir. Diğer bir taraftan sabit kazanç değeri yakınsama hızı ile uç işlevci hızları arasında bir ödünleşmeye sebep olmaktadır. GTGS işleyişi sırasında özniteliklerin görüş alanını terk ederek GTGS'nin tamamen durmasına sebep olması da yaygın bir sorundur.

$\mathrm{Bu}$ çalışmada bu sorunları çözmek için önerilen akıllı yaklaşımların endüstriyel tipte bir robot manipülatör üzerine uygulanması hedeflenmiştir. Uygulamanın ilk aşaması olarak akıllı yaklaşımcı birimler etkileşim matrisinin tersinin yerini alması ve tekillik sorunu ortadan kaldırması hedeflenmiştir. İkinci aşama olarak sabit kazanç yerine her çevrimde hata ve hata türevinin değerine göre kazanç hesabı yapan bir bulanık mantık birimi kullanılmıştır. Ayrıca manipülatör tekilliklerinden uzak durmayı sağlayan hareketliliğin de bu birime bir giriş olarak verilmesi amaçlanmıştır. Üçüncü aşamada ise alınan görüntü düzleminde bölgeler tanımlanmış, bir bulanık mantık birimi yardımıyla özniteliklerin görüş alanı içerisinde kalması sağlanmıştır. Çalışmada tüm gerçeklemelere dair deneysel sonuçlar sunulmuştur.

İlk aşamadaki akıllı yakınsayıcılarda kabul edilebilir seviyede yakınsama sağlansa da YSA ve EÖM öznitelikleri görüntü dışına çıkararak ıraksamaya sebep oldukları GTGS üzerinde yapılan deneyler sonucunda görülmüştür. RTA yakınsayıcı ise tıpkı klasik GTGS gibi sonuç vermekte ve aynı başarımı yakalamaktadır.

İkinci aşamadaki BM tabanlı değişken kazançta ise önerilen GTGS sisteminin klasik sisteme göre yaklaşık \%25.35 daha hızlı yakınsadığı, hız değerlerinde büyük artışların olmadığı ve hız limitleri içerisinde kaldığı görülmektedir. Böylece önerilen sistemle hız limitleri içinde daha hızlı yakınsama sağlandığı söylenebilmektedir.

Üçüncü aşamadaki BM tabanlı görüş alanı koruma yaklaşımında ise güvenli bölgeden çıkan özniteliklerin zıt yönlü tanımlanan hızlarla güvenli bölgeye sürüklendiği fakat burada kalmak yerine tekrar klasik GTGS tarafından tehlikeli bölgelere tekrar sürüklendikleri ve tekrar BM tabanlı görüş alanı koruma ile güvenli bölgeye çekildikleri gözlemlenmiştir. Belirli iterasyon diliminde devam eden bu durum sonucunda hız ve hata sinyallerinde çatırtılar ortaya çıkmıştır. Bu çatırtının yok edilmesi ve özniteliklerin güvenli bölgeye çekildikten sonra bu bölgede kalmasını sağlamak için denemeler devam etmektedir. 
Önerilen sistemle üç farklı GTGS problemine sunulan çözümlerin aynı anda beraber çalışabilirliği için yapılan denemelerde değişken kazancın getirdiği ani ve büyük değişimler doğrultusunda yakınsayıcılar istenilen başarımı elde edememiş ve GTGS yakınsayamadan eldeki öznitelikler BM tabanlı görüş alanı korumasını da aşarak görüntü dışına çıkmışlardır. Burada özniteliklerin görüntü dışına çıkışları yine ani gelen değişimlere bağlı ani hız değişimlerinden ve BM biriminin oluşturduğu zıt yönlü hızların yeterli kalamamasındandır. Gelecek çalışmalarda bu üç çözümde gerekli iyileştirmeler yapılarak beraber istenen başarımda çalışmaları hedeflenmektedir. Ayrıca yapay zeka birimleri devreye girdiğinde gerçek zamanlı çalışmanın zor olduğu, gelecek çalışmalarda bu birimleri hızlandıracak GPU tabanlı çözümlerin kullanılması hedeflenmektedir.

Önerilen sistemin görüntüye bağlı olarak özniteliklerde görülebilecek gürültülere karşı gürbüz olması önerilen sistemin amaçlarındandır. Bu amaç doğrultusunda önerilen sistemde sadece BM tabanlı değişken kazanç için öznitelik gürültüsü altında denemeler yapılmış, benzer başarıma yakın sonuçlar elde edilerek sistemin gürbüzlügü kanıtlanmıştır. Gelecek çalışmalarda bu üç çözümün beraber çalıştı̆̆ durumda da gürbüzlük hedeflenmektedir.

\section{TEŞEKKÜR}

Bu çalışma TÜBİTAK tarafından 3001 kodlu Başlangıç Projeleri kapsamında TÜBİTAK-117E511 numarası ile desteklenmiştir.

\section{KAYNAKLAR}

[1] Hill, J.\& Park W. T. (1979). Real time control of a robot with a mobile camera. Proceedings of the 9th ISIR, 233-246.

[2] Hutchinson, S. A., Hager G. D. \& Corke P. I. (1996). A tutorial on visual servo control. IEEE Int. Conf. Robot. Autom., cilt. 12, no. 5, 651-670, doi: 10.1109/70.538972.

[3] Chaumette F. \& Hutchinson S. (2006). Visual servo control. I. Basic approaches. IEEE Robot. Autom. Mag., cilt 13, no. 4, 82-90, doi: 10.1109/MRA.2006.250573.

[4] Collewet C., Marchand E. \& Chaumette F. (2008). Visual servoing set free from image processing. Proc. IEEE Int. Conf. Robot. Autom., 81-86, doi: 10.1109/ROBOT.2008.4543190.

[5] Kallem V., Swensen J. P., Hager G. D. \& Cowan N. J. (2007). Kernel-based visual servoing. IEEE/RSJ International Conference on Intelligent Robots and Systems, 1975-1980.

[6] Tahri O. \& Chaumette F. (2005). Point-based and region-based image moments for visual servoing of planar objects. IEEE Trans. Robot., cilt. 21, no. 6, 1116-1127, doi: 10.1109/TRO.2005.853500.

[7] Bakthavatchalam M., Tahri O. \& Chaumette F. (2018). A direct dense visual servoing approach using photometric moments. IEEE Trans. Robot., cilt. 34, no. 5, 1226-1239, doi: 10.1109/TRO.2018.2830379.

[8] Bateux Q. \& Marchand E. (2017). Histograms-based visual servoing. IEEE Robotics and Automation Letters, cilt. 2, no. 1, 80-87, 2017.

[9] Bourquardez O., Mahony R., Hamel T. \& Chaumette F. (2006). Stability and performance of image based visual servo control using first order spherical image moments. IEEE/RSJ Int. Conf. Intell. Robot. Syst., 4304-4309, doi: 10.1109/IROS.2006.281963.

[10] Malis E., Chaumette F. \& Boudet S. (1999). 2 1/2 D visual servoing. IEEE Trans. Robot. Autom., cilt. 15, no. 2, 238-250, doi: 10.1109/70.760345.

[11] Corke P. I.\& Hutchinson S. A. (2001). A new partitioned approach to image-based visual servo control. IEEE Trans. Robot. Autom., cilt.17, no. 4, 507-515, doi: 10.1109/70.954764.

[12] He Z., Wu C., Zhang S. \& Zhao X. (2019). Moment-based 2.5-D visual servoing for textureless planar part 
grasping for textureless planar part grasping. IEEE Transactions on Industrial Electronics, cilt. 66, no. 10, 7821-7830.

[13] Chaumette F. (1998). Potential problems of stability and convergence in image-based and position-based visual servoing," Lecture Notes in Control and Information Sciences, 66-78.

[14] Kumar P. P. \& Behera L. (2010). Visual servoing of redundant manipulator with Jacobian matrix estimation using self-organizing map. Rob. Auton. Syst., cilt. 58, no. 8, 978-990, doi: 10.1016/j.robot.2010.04.001.

[15] Kosmopoulos D. I. (2011). Robust Jacobian matrix estimation for image-based visual servoing. Robot. Comput. Integr. Manuf., cilt. 27, no. 1, 82-87, doi: 10.1016/j.rcim.2010.06.013.

[16] Zhong X., Zhong X. \& Peng X. (2015). Robots visual servo control with features constraint employing Kalman-neural-network filtering scheme. Neurocomputing, cilt. 151, 268-277, doi: 10.1016/j.neucom.2014.09.043.

[17] Gonçalves P. J., Mendonça L. F., Sousa J. M. C. \& Pinto J. R. C. (2008). Uncalibrated eye-to-hand visual servoing using inverse fuzzy models. IEEE Trans. Fuzzy Syst., cilt. 16, no. 2, 341-353, 2008.

[18] Mansard N. \& Chaumette F. (2007). Task sequencing for high-level sensor-based control. IEEE Trans. Robot., cilt. 23, no. 1, 60-72, doi: 10.1109/TRO.2006.889487.

[19] Kermorgant O.\& Chaumette F. (2014). Dealing with constraints in sensor-based robot control. IEEE Trans. Robot., cilt. 30, no. 1, 244-257.

[20] Chesi G., Hashimoto K., Prattichizzo D. \& Vicino A. (2004). Keeping features in the field of view in eyein-hand visual servoing: A switching approach. IEEE Trans. Robot., cilt. 20, no. 5, 908-913, doi: 10.1109/TRO.2004.829456.

[21] Yoshikawa T. (1985). Manipulability of robotic mechanisms. Int. J. Rob. Res., cilt. 4, no. 2, 3-9, 1985.

[22] Zhao Z. Y., Tomizuka M., \& Isaka S. (1993). Fuzzy Gain Scheduling of PID Controllers. IEEE Trans. Syst. Man Cybern., cilt. 23, no. 5, 1392-1398, doi: 10.1109/21.260670.

[23] Mezouar Y. \& Chaumette F. (2002). Path planning for robust image-based control. IEEE Trans. Robot. Autom., cilt. 18, no. 4, 534-549.

[24] Chesi G. \& Hung Y. S. (2007). Global path-planning for constrained and optimal visual servoing. IEEE Trans. Robot., cilt. 23, no. 5, 1050-1060.

[25] Gonzales R. C.\& Woods R. E. (2008). Digital Image Processing, 3.rd. Pearson.

[26] Haykin S. (1998). Neural Networks: A Comprehensive Foundation, 2nd ed. Upper Saddle River, NJ, USA: Prentice Hall PTR.

[27] Huang G., Zhou H., Ding X. \& Zhang R. (2012). Extreme learning machine for regression and multiclass classification. IEEE Trans. Syst. Man, Cybern. B Cybern., cilt. 42, no. 2, 513-529.

[28] Janabi-Sharifi F., Deng L. \& Wilson W. J. (2011). Comparison of basic visual servoing methods. IEEE/ASME Trans. Mechatronics, cilt. 16, no. 5, 967-983, 2011, doi: 10.1109/TMECH.2010.2063710. 